\title{
Hydrolysis of phytate and formation of inositol phosphate isomers without or with supplemented phytases in different segments of the digestive tract of broilers
}

\author{
Ellen Zeller ${ }^{1}$, Margit Schollenberger ${ }^{1}$, Imke Kühn ${ }^{2}$ and Markus Rodehutscord ${ }^{1} *$ \\ ${ }^{1}$ Institut für Tierernährung, Universität Hohenheim, 70599 Stuttgart, Germany \\ ${ }^{2}$ AB Vista Feed Ingredients, 64293 Darmstadt, Germany
}

(Received 27 March 2014 - Final revision received 31 July 2014 - Accepted 3 November 2014)

Journal of Nutritional Science (2015), vol. 4, e1, page 1 of 12

doi:10.1017/jns.2014.62

Abstract

The objective was to characterise degradation of myo-inositol 1,2,3,4,5,6-hexakis (dihydrogen phosphate) (Ins $\mathrm{P}_{6}$ ) and formation of inositol phosphate (InsP) isomers in different segments of the broiler digestive tract. Influence of an Aspergillus niger (PhyA) and two Escherichia coli-derived (PhyE1 and PhyE2) phytases was also investigated. A total of 600 16-d-old broilers were allocated to forty floor pens (ten pens per treatment). Low-P (5.2 g/ kg DM) maizesoyabean meal-based diets were fed without (basal diet; BD) or with a phytase added. On day 25, digesta from different digestive tract segments were pooled per segment on a pen-basis, freeze-dried and analysed for $\mathrm{P}$, InsP isomers and the marker $\mathrm{TiO}_{2}$. InsP $\mathrm{P}_{6}$ degradation until the lower ileum (74 $\%)$ in BD-fed birds showed a high potential of broilers and their gut microbiota to hydrolyse Ins $_{6}$ in low-P diets. Different InsP patterns in different

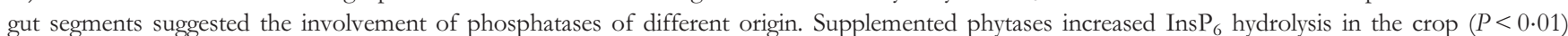
but not in the lower ileum. Measurements in the crop and proventriculus/gizzard confirmed published in vitro degradation pathways of 3-and 6-phytases for the first time. In the intestinal segments, specifically formed $\mathrm{Ins}_{4-5}$ isomers of supplemented phytases were still present, indicating further activity of these enzymes. Myo-inositol tetrakisphosphate $\left(\mathrm{InsP}_{4}\right)$ accumulation differed between PhyE1 and PhyE2 compared with PhyA in the anterior segments of the gut $(P<0.01)$. Thus, the hydrolytic cleavage of the first phosphate group is not the only limiting step in phytate degradation in broilers.

Key words: Inositol phosphate isomers: Phytate hydrolysis: Phytases: Broilers

Phytate represents the primary storage form of $\mathrm{P}$ in plant seeds. It is defined as any salt of phytic acid (myo-inositol 1,2,3,4,5,6-hexakis (dihydrogen phosphate) or $\mathrm{InsP}_{6}$ ). The utilisation of $\mathrm{Ins}_{6}-\mathrm{P}$ depends on $\mathrm{Ins}_{6}$ hydrolysis because $\mathrm{P}$ absorption occurs mainly as orthophosphate ${ }^{(1)}$. Ins $\mathrm{P}_{6^{-}}$ hydrolysing enzymes such as phytases (myo-inositol hexakisphosphate phosphohydrolases) catalyse the hydrolytic cleavage of $\mathrm{InsP}_{6}$ and its salts via several phosphorylated intermediary products (myo-inositol pentakis-, tetrakis-, tris-, bis- and monophosphate) down to myo-inositol. The International Union of Pure and Applied Chemistry/
International Union of Biochemistry differentiates among three types of phytases: 3-phytases (EC 3.1.3.8), 4-/6-phytases (EC 3.1.3.26) and 5-phytases (EC 3.1.3.72), a classification that refers to the initiating position on the inositol ring during in vitro Ins $\mathrm{P}_{6}$ dephosphorylation. The 6-phytases usually originate from plants and initiate hydrolysis at the D-4 (L-6) position of Ins $\mathrm{P}_{6}^{(2)} ; 3$-phytases are usually of microbial origin (starting hydrolysis at the D-3 (L-1) position), such as the fungal Aspergillus niger phytase ${ }^{(3-5)}$ or the bacterial Pseudomonas phytase ${ }^{(2)}$. However, Escherichia coli phytase as an exception was characterised as a 6-phytase (starting hydrolysis at the D-6

Abbreviations: $\mathrm{BD}$, basal diet; InsP, inositol phosphate; $\mathrm{Ins}_{3}$, myo-inositol trisphosphate; $\mathrm{Ins}_{4} \mathrm{P}_{4}$, myo-inositol tetrakisphosphate; Ins $\mathrm{P}_{5}$, myo-inositol pentakisphosphate; Ins $\mathrm{P}_{6}$, myo-inositol 1,2,3,4,5,6-hexakis (dihydrogen phosphate); PhyA, Aspergillus-derived phytase Finase ${ }^{\circledR}$ P; PhyE1, Escherichia coli-derived phytase Quantum ${ }^{\circledR}$; PhyE2, E. coli-derived phytase Quantum ${ }^{\circledR}$ Blue; tP, total P.

* Corresponding author: M. Rodehutscord, email inst450@uni-hohenheim.de 
(L-4) position) ${ }^{(6,7)}$. We are not aware of any study that has investigated whether this in vitro-based classification is reflected also in the pathways of Ins $_{6}$ degradation in the more complex and variable environment of the digestive tract of broilers.

Ins $\mathrm{P}_{6}-\mathrm{P}$ has long been assumed to be poorly used by avian species because of the lack of sufficient endogenous Ins $\mathrm{P}_{6}$-hydrolysing enzymes and the denaturation of intrinsic plant phytases in the stomach and during feed manufacture. In broilers, although the activity of endogenous mucosal phytase in the small intestine has been described ${ }^{(8-10)}$, its contribution to $\mathrm{Ins}_{6}$ hydrolysis has been considered almost negligible. Although some more recent studies have indicated that Ins $\mathrm{P}_{6}-\mathrm{P}$ is highly available for broilers ${ }^{(11)}$, the origin of phytase activity in the digestive tract is controversial. Some authors have suggested that endogenous mucosal phytase of the small intestine is very capable of high $\operatorname{Ins}_{6}$ hydrolysis ${ }^{(12,13)}$. Others hypothesise that Ins $\mathrm{P}_{6}$ is hydrolysed by phytases produced by micro-organisms present in the small intestine and particularly in the $\operatorname{caeca}^{(14,15)}$.

It is not known which positional inositol phosphate (InsP) isomers are formed by different phytases in the digestive tract of avian species. Some studies have described different positional isomers of $\mathrm{Ins}_{6}$ degradation products in several segments of the digestive tract in pigs ${ }^{(16-18)}$, but the variations in digestive tract physiology and anatomy between pigs and birds (for example, passage rate, digesta viscosity, presence of a crop, variable $\mathrm{pH}$ values) caution against assuming that findings in pigs will be similar to that in broilers. One consequence of the uncertainties regarding the availability of Ins $\mathrm{P}_{6}-\mathrm{P}$ is that commercial poultry diets are supplemented with mineral P sources. This costly supplementation increases the $\mathrm{P}$ concentration in excreta, which may contribute to environmental problems such as eutrophication of surface waters and exhaustion of global raw phosphate resources $^{(19)}$. An understanding of the rate of degradation of $\mathrm{Ins}_{6}$ to the different positional InsP isomers along the digestive tract would enable a more precise alignment of the feed composition to the birds' $\mathrm{P}$ requirements and thus increase the likelihood of averting a 'potential planet phosphate crisis ${ }^{(20)}$. Phytases of different origin, varying in their properties, such as $\mathrm{pH}$ optimum, proteolytic stability and kinetic efficiency, may differ in effectiveness with transit as the conditions along the digestive tract change. The in vitrodetermined $\mathrm{pH}$ optimum of most phytase supplements is particularly aligned to the conditions of the anterior segments of the digestive $\operatorname{tract}^{(21)}$.

The first objective of the present study therefore was to characterise $\mathrm{Ins}_{6}$ hydrolysis and formation of InsP isomers in different segments of the digestive tract of broilers. The second objective was to investigate the $\mathrm{Ins}_{6} \mathrm{P}_{6}$ degradation pattern of different phytase additives and their effectiveness in releasing phosphate in broilers and to compare the findings with known in vitro properties. In the absence of supplementary phytase, $\mathrm{InsP}_{6}$ was hypothesised to be mainly hydrolysed in the posterior intestinal segments of the digestive tract. In contrast, the different phytase supplements were expected to result in greater overall rates of $\mathrm{InsP}_{6}$ hydrolysis and to elicit different Ins $\mathrm{P}$ patterns in the anterior segments.

\section{Materials and methods}

\section{Experimental diets}

The basal diet (BD) was calculated to contain adequate levels of all nutrients according to the recommendations of the Gesellschaft für Ernährungsphysiologie (Society for Nutrition Physiology) ${ }^{(22)}$ with the exception of $\mathrm{Ca}$ and P. It was mainly based on maize and solvent-extracted soyabean meal (Table 1). Ingredients were chosen to obtain low concentrations of total $\mathrm{P}(\mathrm{tP})$, high proportions of $\mathrm{Ins}_{6} \mathrm{P}_{6} \mathrm{P}$ in $\mathrm{tP}$ and low intrinsic phytase activity. Concentrations of $\mathrm{Ca}$ and $\mathrm{tP}$ were calculated to be 7.9 and $5.0 \mathrm{~g} / \mathrm{kg}$ of DM, respectively, and these levels were confirmed by analyses (Table 1). Titanium dioxide $\left(\mathrm{TiO}_{2}\right)$ was included at a rate of $5 \mathrm{~g} / \mathrm{kg}$ as the indigestible marker, and the intended Ti concentration was confirmed by analysis.

Diets were prepared in the certified feed mill facilities of Hohenheim University's Agricultural Experiment Station. The $\mathrm{BD}$ was mixed in one lot and divided into four equal parts. One part remained without phytase supplementation (BD). The other parts were supplemented with three different phytase-containing products at an intended activity of $500 \mathrm{U} / \mathrm{kg}$ of diet. The supplemented phytase products were a commercial $A$. niger-derived 3-phytase (PhyA; Finase ${ }^{\circledR}$ P, EC 3.1.3.8; AB Vista) and two E. coliderived thermotolerant 6-phytases (PhyE1 (Quantum ${ }^{\circledR}$ ) and PhyE2 (Quantum ${ }^{\circledR}$ Blue); EC 3.1.3.26; AB Vista). To ensure adequate mixing of each phytase, premixes of each product were prepared by mixing with a small amount of the BD before addition to the treatment diet. Diets were pelleted through a 3-mm die without using steam. The temperature of pellets measured immediately after release from the press ranged between $57^{\circ} \mathrm{C}$ and $69^{\circ} \mathrm{C}$. Representative samples of the diets were taken for analyses of phytase activity, proximate nutrients, DM, Ca, tP, Ti and InsP isomers. The samples were pulverised using a vibrating cup mill (type 6-TOPF; Siebtechnik $\mathrm{GmbH}$ ) and stored at $4^{\circ} \mathrm{C}$ until further handling. The experimental diets contained similar concentrations of myo-inositol pentakisphosphate (Ins $\mathrm{P}_{5}$ ) and Ins $\mathrm{P}_{6}$ (Table 1). The Ins $\mathrm{P}_{6}-\mathrm{P}$ was $57 \%$ of tP in the diets on average and that of Ins $\mathrm{P}_{5}-\mathrm{P}$ was $3 \%$ of tP. Lower InsP isomers were not detected in the diets. The phytase activity of the BD was below the limit of detection, but phytase activities of the supplemented diets ranged between 399 and $467 \mathrm{U} / \mathrm{kg}$ of diet.

\section{Animals and management}

The study was conducted in the Agricultural Experiment Station of Hohenheim University, location Lindenhöfe in Eningen (Germany). It was approved by the Animal Welfare Commissioner of the University in accordance with the German Welfare Legislation. Birds underwent routine vaccination against coccidiosis, Newcastle disease and infectious bursal disease on 3,10 and $14 \mathrm{~d}$ of age, respectively.

A total of 600 unsexed Ross 308 broilers aged $1 \mathrm{~d}$ were obtained from a commercial hatchery (Brüterei Süd $\mathrm{GmbH} \&$ Co.) and randomly allocated to forty floor pens (approximately $1.5 \mathrm{~m} \times 1.5 \mathrm{~m}$ ) bedded with wood shavings. Each pen had fifteen birds. The room temperature was 34 and $32^{\circ} \mathrm{C}$ on days 1 and 2 , respectively. Thereafter, the temperature was reduced in steps of $0.5^{\circ} \mathrm{C}$ per $\mathrm{d}$, reaching $20^{\circ} \mathrm{C}$ on day 25 . Artificial lighting 
Table 1. Ingredient composition and analysed characteristics of the experimental diets

\begin{tabular}{|c|c|c|c|c|}
\hline & BD & PhyA & PhyE1 & PhyE2 \\
\hline \multicolumn{5}{|l|}{ Ingredients ( $\mathrm{g} / \mathrm{kg}$ as fed) } \\
\hline Maize & 553 & & & \\
\hline $\begin{array}{l}\text { Solvent-extracted } \\
\text { soyabean meal ( } 48 \% \\
\text { crude protein) }\end{array}$ & 400 & & & \\
\hline Soyabean oil & 20 & & & \\
\hline Limestone & 13 & & & \\
\hline Sodium chloride & 1 & & & \\
\hline Choline chloride & 2 & & & \\
\hline Sodium bicarbonate & 3 & & & \\
\hline Mineral $\mathrm{mix}^{*}$ & 1 & & & \\
\hline Vitamin mix† & 2 & & & \\
\hline Titanium dioxide & 5 & & & \\
\hline \multicolumn{5}{|l|}{$\begin{array}{l}\text { Analysed characteristics of } \\
\text { the diets }\end{array}$} \\
\hline $\mathrm{DM}(\mathrm{g} / \mathrm{kg})$ & 895 & 896 & 896 & 895 \\
\hline Crude ash $(\mathrm{g} / \mathrm{kg})$ & 53 & 52 & 53 & 51 \\
\hline Crude protein $(\mathrm{g} / \mathrm{kg})$ & 230 & 231 & 232 & 226 \\
\hline Diethyl ether extract $(\mathrm{g} / \mathrm{kg})$ & 54 & 53 & 52 & 53 \\
\hline Crude fibre $(\mathrm{g} / \mathrm{kg})$ & 23 & 21 & 24 & 22 \\
\hline $\begin{array}{l}\text { Metabolisable energy } \\
\text { (calculated) (MJ/kg) }\end{array}$ & $12 \cdot 5$ & $12 \cdot 5$ & $12 \cdot 5$ & $12 \cdot 5$ \\
\hline Phytase activity (U/kg)‡ & $<50$ & $399 \S$ & 467 & 442 \\
\hline $\mathrm{Ca}(\mathrm{g} / \mathrm{kg} \mathrm{DM})$ & 7.5 & 7.6 & 7.4 & $7 \cdot 3$ \\
\hline Total P (g/kg DM) & $5 \cdot 2$ & $5 \cdot 3$ & $5 \cdot 2$ & $5 \cdot 2$ \\
\hline $\operatorname{lnsP}_{6}-\mathrm{P}(\mathrm{g} / \mathrm{kg} \mathrm{DM})$ & 3.0 & 3.0 & 3.0 & 3.0 \\
\hline $\begin{array}{l}\text { Ins }(1,2,3,4,6) \mathrm{P}_{5}(\mathrm{nmol} / \mathrm{g} \\
\mathrm{DM})\end{array}$ & ND & $<\mathrm{LOQ}$ & $<\mathrm{LOQ}$ & $<\mathrm{LOQ}$ \\
\hline $\begin{array}{l}\text { Ins }(1,2,3,4,5) \mathrm{P}_{5}(\mathrm{nmol} / \mathrm{g} \\
\mathrm{DM})\end{array}$ & 200 & 200 & 300 & 300 \\
\hline $\begin{array}{l}\text { Ins }(1,2,4,5,6) P_{5}(\mathrm{nmol} / \mathrm{g} \\
\mathrm{DM})\end{array}$ & 600 & 600 & 600 & 600 \\
\hline $\begin{array}{l}\text { Ins }(1,3,4,5,6) P_{5}(\mathrm{nmol} / \mathrm{g} \\
\mathrm{DM})\end{array}$ & ND & ND & ND & ND \\
\hline $\operatorname{lnsP}_{6}(\mathrm{nmol} / \mathrm{g} \mathrm{DM})$ & 15900 & 16000 & 16200 & 16100 \\
\hline
\end{tabular}

BD, basal diet; PhyA, BD supplemented with Aspergillus niger 3-phytase, Finase ${ }^{\circledR} \mathrm{P}$; PhyE1, BD supplemented with Escherichia coli 6-phytase, Quantum ${ }^{\circledR}$; PhyE2, BD supplemented with $E$. coli 6-phytase, Quantum ${ }^{\circledR}$ Blue; Ins $\mathrm{P}_{6}$, myo-inositol 1,2,3,4,5,6-hexakis (dihydrogen phosphate); InsP $\mathrm{P}_{5}$, myo-inositol pentakisphosphate; ND, not detected; LOQ, limit of quantification.

* P-free: Mineral mix (Gelamin SG 1 Geflügel, GFT MBH), provided per kg of complete diet: $15 \mathrm{mg} \mathrm{Cu} ; 1.6 \mathrm{mg} \mathrm{I} ; 90 \mathrm{mg} \mathrm{Fe} ; 120 \mathrm{mg} \mathrm{Mn} ; 80 \mathrm{mg} \mathrm{Zn;0.5} \mathrm{mg} \mathrm{Se;} 0.6$ mg Co.

† Vitamin mix (Raiffeisen Kraftfutterwerke Süd $\mathrm{GmbH}$ ), provided per kg of complete diet: $3.6 \mathrm{mg}$ retinol; $75 \mu \mathrm{g}$ cholecalciferol; $30 \mathrm{mg} \alpha$-tocopherol; $2.4 \mathrm{mg}$ menadione; 3 $\mathrm{mg}$ thiamin; $6 \mathrm{mg}$ riboflavin; $6 \mathrm{mg}$ pyridoxine; $0.03 \mathrm{mg}$ cyanocobalamin; $50 \mathrm{mg}$ nicotinic acid; $14 \mathrm{mg}$ pantothenic acid; $0.1 \mathrm{mg}$ biotin; $1 \mathrm{mg}$ pteroyl(mono)glutamic acid. † Determined at $\mathrm{pH} 4.5$ and $60^{\circ} \mathrm{C}$

$\S$ Determined at $\mathrm{pH} 5.0$ and $37^{\circ} \mathrm{C}$.

was provided with an intensity of 10 lux. During the first $2 \mathrm{~d}$, the animal house was illuminated continuously. A lighting regimen of $18 \mathrm{~h}$ light and $6 \mathrm{~h}$ dark was applied from day 3 onwards. Feed and tap water were available for ad libitum consumption. Until day 15, the animals were fed a commercial starter diet containing $1.10 \% \mathrm{Ca}, 0.55 \% \mathrm{tP}, 22.0 \%$ crude protein, $6.6 \%$ diethyl ether extract and $12.5 \mathrm{MJ}$ metabolisable energy $/ \mathrm{kg}$. On day 16, the birds were weighed, and ten pens of fifteen birds were assigned to each of the four dietary treatments and distributed in a completely randomised block design.

\section{Sampling and analytical methods}

At $25 \mathrm{~d}$ of age, the animals were asphyxiated by $\mathrm{CO}_{2}$ exposure and weighed. To standardise feed intake before sampling and thus retention time of feed in the crop, birds were deprived of feed for $1 \mathrm{~h}$. The feed troughs were then moved back into the pens $1 \mathrm{~h}$ before the birds were killed, on an individual-pen basis to ensure the same time schedule for all replicates. The first samples were taken $1 \mathrm{~h}$ after the beginning of the light period. Samples from five parts of the digestive tract (crop, proventriculus and gizzard (pooled), duodenum and jejunum (pooled), the terminal part of the ileum (defined as the posterior two-thirds of the section between Meckel's diverticulum and $2 \mathrm{~cm}$ anterior to the ileo-caeco-colonic junction $\left.{ }^{(23)}\right)$ and the caeca) were taken. After opening of the abdominal cavity, the total digestive tract was removed except the crop. Digesta of the intestinal segments were gently flushed out with doubledistilled water whereas the segments of the anterior digestive tract (crop, proventriculus and gizzard) were cut open and purged. The samples were pooled for all birds from one pen separately for each segment, immediately frozen at $-18^{\circ} \mathrm{C}$, freezedried (type Delta 1-24; Martin Christ Gefriertrocknungsanlagen $\mathrm{GmbH}$ ) and pulverised as explained for the diets. The ground samples were stored at $4^{\circ} \mathrm{C}$ until analysis.

Concentrations of proximate nutrients were determined according to the official methods in Germany (Verband Deutscher Landwirtschaftlicher Untersuchungs- und Forschungsanstalten; VDLUFA) ${ }^{(24)}$. Feed samples were analysed for DM and crude ash (method 3.1), crude protein (method 4.1.1), diethyl ether extract (method 5.1.1) and crude fibre (method 6.1.1). The concentrations of $\mathrm{Ca}, \mathrm{tP}$ and $\mathrm{Ti}$ in diet and digesta samples were determined by a modification of the method of Boguhn et al. ${ }^{(25)}$. In brief, $20 \mathrm{ml}$ of sulfuric acid $(18 \mathrm{~mol} / \mathrm{l})$ and $2.5 \mathrm{ml}$ of nitric acid $(14 \mathrm{~mol} / \mathrm{l})$ were added to $0.4 \mathrm{~g}$ of sample. Solutions were heated from 100 to $200^{\circ} \mathrm{C}$ for $30 \mathrm{~min}$ in a block digestion system equipped with a system to trap nitrous gases (Behr K $20 \mathrm{~L}$; Behr Labor-Technik $\mathrm{GmbH}$ ). After cooling to $100^{\circ} \mathrm{C}, 2.5 \mathrm{ml}$ of the nitric acid were added. Following heating from 225 up to $300^{\circ} \mathrm{C}$ for $75 \mathrm{~min}$ and subsequent cooling to room temperature, the solutions were filled with double-distilled water to a volume of $500 \mathrm{ml}$ and filtered. The $\mathrm{Ca}, \mathrm{P}$ and Ti concentrations of the solutions were measured using an inductively coupled plasma optical emission spectrometer (VISTA PRO; Varian Inc.) at specific wavelengths for each element according to Shastak et al. ${ }^{(26)}$.

For the analysis of InsP isomers in diet and digesta samples, $1.0 \mathrm{~g}$ of the sample was extracted for $30 \mathrm{~min}$ with $10 \mathrm{ml}$ of a solution containing $0 \cdot 2 \mathrm{~m}$-EDTA and $0.1 \mathrm{~m}$-sodium fluoride $(\mathrm{pH}=10)$ as phytase inhibitor using a rotary shaker. The samples were centrifuged at $12000 \mathrm{~g}$ for $15 \mathrm{~min}$ and the supernatant fraction was removed and preserved on ice. The residue was re-suspended in $5 \mathrm{ml}$ of the EDTA-sodium fluoride solution and extracted again for $30 \mathrm{~min}$. The supernatant fractions of the two extraction steps were then combined. A quantity of $1 \mathrm{ml}$ of the pooled supernatant fraction was centrifuged at $14000 \mathrm{~g}$ for $15 \mathrm{~min}$ and $0.5 \mathrm{ml}$ of the resulting supernatant fraction were filtered through a $0.2 \mu \mathrm{m}$ cellulose acetate filter (VWR) into a Microcon filter (cut-off $30 \mathrm{kDa}$ ) device (Millipore) and centrifuged again at $14000 \mathrm{~g}$ for $30 \mathrm{~min}$. Throughout the whole extraction procedure, the samples were kept below $6^{\circ} \mathrm{C}$. The procedure for caecal samples was slightly different: glass beads (diameter $0.6 \mathrm{~mm}$ ) were added before extraction. To obtain a clear supernatant fraction for the caecal 
matrix, the extracts were centrifuged for $30 \mathrm{~min}$ at $12000 \mathrm{~g}$ and $6^{\circ} \mathrm{C}$. Filtrates were analysed by high-performance ion chromatography and UV detection at $290 \mathrm{~nm}$ after post-column derivatisation using an ICS-3000 system (Dionex). InsP with different degrees of phosphorylation $\left(\mathrm{Ins}_{3-6}\right)$ and their positional isomers were separated, without enantiomer differentiation, on a Carbo Pac PA 200 column and corresponding guard column. $\mathrm{Fe}\left(\mathrm{NO}_{3}\right)_{3}$ solution $\left(1 \mathrm{~g} / 1, \mathrm{Fe}\left(\mathrm{NO}_{3}\right)_{3} \cdot 9 \mathrm{H}_{2} \mathrm{O}\right.$, product no. 103883; Merck KGaA) in $\mathrm{HClO}_{4}(20 \mathrm{~g} / 1$, product no. 100518; Merck KGaA) was used as reagent for derivatisation according to Philippy \& Bland ${ }^{(27)}$. The elution order of InsP isomers was established using commercial standards if available. Ins $_{5}$ isomer standards were purchased from Sirius Fine Chemicals. Seven out of nine myo-inositol tetrakisphosphate (Ins $\mathrm{P}_{4}$ ) and nine out of twelve myo-inositol trisphosphate $\left(\mathrm{InsP}_{3}\right)$ isomer standards were available from Santa Cruz Biotechnology. One detected peak out of the group of $\mathrm{Ins}_{4}$ isomers could not be attributed but was presumed to be Ins $(1,2,4,6) \mathrm{P}_{4}$ by comparison with the elution order of Chen \& $\mathrm{Li}^{(28)}$, who used similar chromatographical conditions. A clear identification of the $\mathrm{Ins}_{3}$ isomers present was not possible. However, a peak was detected, corresponding in its retention time to the retention time of $\operatorname{Ins}(1,3,4) \mathrm{P}_{3}, \operatorname{Ins}(1,4,6) \mathrm{P}_{3}$, Ins $(1,2,6) \mathrm{P}_{3}$, Ins $(1,4,5) \mathrm{P}_{3}$ and Ins $(2,4,5) \mathrm{P}_{3}$ (out of the available standards), which all coeluted under the conditions used. Ins $\mathrm{P}_{2}$ and Ins $\mathrm{P}_{1}$ could not be analysed with this method. Ins $\mathrm{P}_{6}$ was used for quantification, and correction factors for differences in detector response for $\mathrm{Ins}_{3-5}$ were used according to Skoglund $e t a .^{(29)}$. The limit of detection was defined for a signal:noise ratio of $3: 1$ and was $0.1 \mu \mathrm{mol} / \mathrm{g}$ of $\mathrm{DM}$ for $\mathrm{InsP}_{3-4}$ isomers and $0.05 \mu \mathrm{mol} / \mathrm{g}$ of $\mathrm{DM}$ for $\mathrm{InsP}_{5}$ isomers and Ins $\mathrm{P}_{6}$. The limit of quantification was defined for a signal: noise ratio of 6:1. A mean for an InsP isomer was calculated only if the isomer was detected in at least five out of the ten samples of one treatment. If the detected value was below the limit of quantification in five or more samples, this was noted as less than the limit of quantification in the tables, and means were not calculated. All samples were analysed in duplicate. The InsP concentration is reported on a DM basis.

Because of differences in the extractability of the phytases used, the phytase activity in the diets was determined under product-specific conditions and expressed as $\mathrm{U} / \mathrm{kg}$ for all diets. Determination of phytase activity was assayed according to the internal, validated methods of the supplier (BD + PhyA: assay at $\mathrm{pH} 5.5$ and $37^{\circ} \mathrm{C} ; \mathrm{BD}, \mathrm{BD}+\mathrm{PhyE} 1$ and $\mathrm{BD}+$ PhyE2: assay at $\mathrm{pH} 4.5$ and $60^{\circ} \mathrm{C}$ ). Both assays were run by Enzyme Services \& Consultancy.

\section{Calculations and statistical analysis}

Body-weight gain, feed consumption and feed:gain ratio were determined on a pen basis for the period between days 16 and 25. Ins $\mathrm{P}_{6}$ hydrolysis and $\mathrm{P}$ net absorption in the digestive tract (y) were calculated for each pen based on the ratio of $\operatorname{Ins}_{6}$ or $\mathrm{P}$ and Ti according to the generally accepted equation:

$$
\begin{aligned}
y(\%)= & 100-100 \times\left(\frac{\text { Ti in the } \operatorname{diet}(\mathrm{g} / \mathrm{kg} \mathrm{DM})}{\text { Ti in the digesta }(\mathrm{g} / \mathrm{kg} \mathrm{DM})}\right) \\
& \times\left(\frac{\mathrm{Ins}_{6} \text { or } \mathrm{P} \text { in the digesta }(\mathrm{g} / \mathrm{kg} \mathrm{DM})}{\mathrm{Ins}_{6} \text { or } \mathrm{P} \text { in the } \operatorname{diet}(\mathrm{g} / \mathrm{kg} \mathrm{DM})}\right)
\end{aligned}
$$

Ins $\mathrm{P}_{6}$ hydrolysis was calculated for the crop, duodenum/ jejunum, lower ileum and caeca. It was not calculated for the proventriculus/gizzard since this segment clearly contained particles of different sizes, which presumably were of variable retention times and thus were not accurately represented by the marker ${ }^{(30)}$. P net absorption was calculated in the duodenum/jejunum and lower ileum.

The percentage of Ins $\mathrm{P}_{3}, \sum$ Ins $\mathrm{P}_{4}$ or $\sum$ Ins $\mathrm{P}_{5}$ in $\sum$ Ins $\mathrm{P}_{3-5}$ was calculated for each treatment and segment to investigate the rapidity of Ins $\mathrm{P}_{6}$ hydrolysis and the extent to which intermediary products with different degrees of phosphorylation were formed. Because Ins $\mathrm{P}_{1-2}$ isomers were not determined, $\sum \mathrm{Ins} \mathrm{P}_{3-5}$ was calculated, representing the sum of identified $\mathrm{Ins}_{6}$ hydrolysis products.

Untransformed data are expressed as means with their standard error or the pooled standard error of the mean. Statistical analysis was performed using the MIXED procedure of the software package SAS for Windows (version 9.1.3; SAS Institute Inc.). Before statistical analysis, data that showed non-normal residuals or heterogeneity of variance were log- or square root-transformed. For data expressed as percentages the arc-sine transformation was used. The following statistical model was chosen: $y_{i j}=\mu+r_{i}+\tau_{j}$ $+\mathrm{e}_{\mathrm{ij}}$, where $\mathrm{y}_{\mathrm{ij}}$ is the $i$ th measurement in the $j$ th treatment, $\mu$ is the overall mean, $r_{i}$ is the $i$ th block (random), $\tau_{j}$ is the effect of the $j$ th treatment (fixed) and $\mathrm{e}_{\mathrm{ij}}$ is the error term. Statistical significance was evaluated by a one-way ANOVA. Mean separation was computed using Fisher's protected least significant difference test $(P \leq 0 \cdot 05)$ only if the overall $F$ test was significant $(P \leq 0 \cdot 05)$.

\section{Results}

The initial body weight was on average $531 \mathrm{~g}$ and was similar between treatments $(P>0 \cdot 05)$. During the $9-\mathrm{d}$ assay period, average body-weight gain, feed consumption and feed:gain ratio were not significantly different between treatments (Table 2).

Table 2. Body-weight (BW) gain, feed consumption $(F C)$ and feed:gain $(F: G)$ ratio of broiler chickens between the ages of 16 and $25 \mathrm{~d}$ (Mean values and pooled standard errors; ten pens per treatment with fifteen birds per pen)

\begin{tabular}{lccccc}
\hline & BD & PhyA & PhyE1 & PhyE2 & Pooled SEM \\
\hline BW gain $(\mathrm{g} / \mathrm{d})^{*}$ & 59 & 58 & 60 & 56 & 1.4 \\
FC $(\mathrm{g} / \mathrm{d})^{*}$ & 95 & 94 & 97 & 92 & 1.9 \\
F:G ratio $(\mathrm{g} / \mathrm{g})^{*}$ & 1.61 & 1.61 & 1.62 & 1.63 & 0.023 \\
\hline
\end{tabular}

BD, basal diet; PhyA, BD supplemented with Aspergillus niger 3-phytase, Finase ${ }^{\circledR}$ P; PhyE1, BD supplemented with Escherichia coli 6-phytase, Quantum ${ }^{\circledR}$; PhyE2, BD supplemented with E. coli 6-phytase, Quantum ${ }^{\circledR}$ Blue.

* The overall $F$ test was not significant. 
Table 3. Myo-inositol 1,2,3,4,5,6-hexakis (dihydrogen phosphate) hydrolysis (\%) in different segments of the digestive tract of broiler chickens (Mean values and pooled standard errors; ten pens per treatment with fifteen birds per pen)

\begin{tabular}{|c|c|c|c|c|c|}
\hline & $\mathrm{BD}$ & PhyA & PhyE1 & PhyE2 & Pooled SEM \\
\hline Crop & $9^{d}$ & $64^{a}$ & $31^{\mathrm{c}}$ & $44^{\mathrm{b}}$ & 4.5 \\
\hline Duodenum/jejunum & 59 & 63 & 65 & 68 & $2 \cdot 8$ \\
\hline Lower ileum & 74 & 74 & 79 & 82 & $3 \cdot 8$ \\
\hline Caeca & $91^{\mathrm{b}}$ & $93^{\mathrm{b}}$ & $95^{\mathrm{a}}$ & $96^{\mathrm{a}}$ & 0.7 \\
\hline
\end{tabular}

BD, basal diet; PhyA, BD supplemented with Aspergillus niger 3-phytase, Finase ${ }^{\circledR}$ P; PhyE1, BD supplemented with Escherichia coli 6-phytase, Quantum ${ }^{\circledR}$; PhyE2, BD supplemented with E. coli 6-phytase, Quantum ${ }^{\circledR}$ Blue.

${ }^{a-d}$ Mean values in a row with unlike superscript letters were significantly different $(P \leq 0.05$; Fisher's protected least significant difference test). Mean separation was only computed if the overall $F$ test was significant.

\section{Myo-inositol 1,2,3,4,5,6-hexakis (dihydrogen phosphate)} hydrolysis

In birds fed the $\mathrm{BD}$, low Ins $\mathrm{P}_{6}$ hydrolysis was measured in the crop ( $9 \%$; Table 3). Average Ins $\mathrm{P}_{6}$ hydrolysis in this treatment was 59, 74 and $91 \%$ until the duodenum/jejunum, the lower ileum and the caeca, respectively.

Supplementation of phytase had a significant effect on $\operatorname{Ins}_{6}$ hydrolysis in the crop $(P<0 \cdot 01)$ but not in the duodenum/ jejunum and lower ileum. In the crop, supplemented phytases significantly increased Ins $\mathrm{P}_{6}$ hydrolysis, and the effect by PhyA $(64 \%)$ was significantly higher than by the other phytase treatments (PhyE1: $31 \%$; PhyE2: $44 \%$ ). Until the duodenum/ jejunum and the lower ileum, the difference in $\mathrm{InsP}_{6}$ hydrolysis between treatments became lower and statistical difference between treatments disappeared. The average $\mathrm{Ins}_{6} \mathrm{P}_{6}$ hydrolysis was $64 \%$ (duodenum/jejunum) and $77 \%$ (lower ileum). InsP 6 hydrolysis up to the caeca was significantly higher with PhyE1 (95\%) and PhyE2 (96\%) compared with the BD (91\%) and PhyA $(93 \%)(P<0 \cdot 01)$.

\section{Net absorption of phosphorus}

In birds fed the BD, a P net absorption of 34 and $57 \%$ was measured until the duodenum/jejunum and lower ileum (Table 4). Supplementation of phytases caused a significant increase in $\mathrm{P}$ net absorption until the duodenum/jejunum (PhyA: 38 \%; PhyE1: 38 \%; PhyE2: $39 \%$ ( $P=0 \cdot 04)$. P net absorption until the lower ileum tended to be higher with PhyE1 (60\%) and was significantly higher with PhyE2 (64\%) compared with PhyA (56\%) and BD (57\%) $(P=0 \cdot 03)$.

\section{Appearance of inositol phosphate isomers}

In the crop digesta of birds fed the $\mathrm{BD}$, an average concentration of 638 and $388 \mathrm{nmol} / \mathrm{g}$ DM was detected for Ins
$(1,2,4,5,6) \mathrm{P}_{5}$ and $\operatorname{Ins}(1,2,3,4,5) \mathrm{P}_{5}$ and lower concentrations were measured for $\operatorname{Ins}(1,2,3,4,6) \mathrm{P}_{5}$ and $\operatorname{Ins}(1,3,4,5,6) \mathrm{P}_{5}$ (Table 5 and Fig. 1(A)). The only detectable inositol tetrakisphosphate Ins $(1,2,5,6) \mathrm{P}_{4}$ was found in low concentration (141 $\mathrm{nmol} / \mathrm{g} \mathrm{DM}$ ), and inositol trisphosphates were not found in the crop in this treatment. About $90 \%$ of $\Sigma \mathrm{InsP}_{3-5}$ in the crop was present as Ins $\mathrm{P}_{5}$ when the $\mathrm{BD}$ was fed. In the proventriculus/gizzard, Ins $(1,2,4,5,6) \mathrm{P}_{5}$ and $\operatorname{Ins}(1,2,3,4,5) \mathrm{P}_{5}$ were the only detectable lower InsP (Table 6), and their concentrations were lower than in the crop. In the duodenum/jejunum, the Ins $\mathrm{P}$ pattern again was more diverse than in the proventriculus/gizzard and different from the crop (Table 7).

The predominant Ins $\mathrm{P}_{5}$ isomer changed in the intestinal segments (Fig. 1 (B) and (C)). Ins $(1,2,3,4,5) \mathrm{P}_{5}$ was the predominant $\mathrm{Ins}_{5}$ isomer in the duodenum/jejunum and the subsequent intestinal segments, accompanied by Ins $(1,2,3,4,6) \mathrm{P}_{5}$ and $\operatorname{Ins}(1,2,4,5,6) \mathrm{P}_{5}$ (Tables $\left.7-9\right)$. In the duodenum/jejunum, high concentrations of $\operatorname{Ins}(1,2,3,4) \mathrm{P}_{4} \quad(355$ $\mathrm{nmol} / \mathrm{g} \mathrm{DM}$ ) were noted and it remained the predominant $\mathrm{Ins}_{4}$ isomer in subsequent segments in the BD treatment. In the lower ileum, the same pattern of $\mathrm{InsP}_{5}$ isomers as in the duodenum/jejunum was found whereas within the $\mathrm{InsP}_{4}$ isomers, Ins $(1,2,4,6) \mathrm{P}_{4}$ also appeared (Table 8). The pattern of the $\mathrm{Ins}_{5}$ isomers in the caeca of birds fed the BD was similar to that of the lower ileum, except that $\operatorname{Ins}(1,3,4,5,6)$ $\mathrm{P}_{5}$ appeared in relatively low concentrations $(75 \mathrm{nmol} / \mathrm{g}$ DM) (Table 9). High concentrations of Ins $(1,2,3,4) \mathrm{P}_{4}(750$ $\mathrm{nmol} / \mathrm{g} \mathrm{DM})$ were detected in the caeca whereas Ins $(1,2,4,6)$ $\mathrm{P}_{4}$ was not found and $\operatorname{Ins}_{3}$ and traces of $\operatorname{Ins}(1,2,5,6) \mathrm{P}_{4}$ appeared.

In the crop digesta of all phytase-containing treatments, the Ins $\mathrm{P}_{5}$ pattern was less broad compared with the BD. For the PhyA treatment, the percentage of $\operatorname{Ins}(1,2,4,5,6) \mathrm{P}_{5}$ in $\sum \operatorname{Ins} \mathrm{P}_{5}$ was significantly higher $(P<0 \cdot 01)$ whereas the percentage of Ins $(1,2,3,4,5) P_{5}$ in $\sum$ Ins $P_{5}$ was significantly lower $(P<0 \cdot 01)$ compared with the three other treatments (Fig. 1 (A)). In

Table 4. Net absorption of phosphorus (\%) in segments of the small intestine of broiler chickens (Mean values and pooled standard errors; ten pens per treatment with fifteen birds per pen)

\begin{tabular}{|c|c|c|c|c|c|}
\hline & $\mathrm{BD}$ & PhyA & PhyE1 & PhyE2 & Pooled SEM \\
\hline Duodenum/jejunum & $34^{\mathrm{b}}$ & $38^{a}$ & $38^{a}$ & $39^{a}$ & 1.2 \\
\hline Lower ileum & $57^{\mathrm{b}}$ & $56^{\mathrm{b}}$ & $60^{a, b}$ & $64^{\mathrm{a}}$ & $2 \cdot 1$ \\
\hline
\end{tabular}

BD, basal diet; PhyA, BD supplemented with Aspergillus niger 3-phytase, Finase ${ }^{\circledR}$ P; PhyE1, BD supplemented with Escherichia coli 6-phytase, Quantum ${ }^{\circledR}$; PhyE2, BD supplemented with E. coli 6-phytase, Quantum ${ }^{\circledR}$ Blue.

${ }^{a, b}$ Mean values in a row with unlike superscript letters were significantly different ( $P \leq 0.05$; Fisher's protected least significant difference test). Mean separation was only computed if the overall $F$ test was significant. 
Table 5. Concentrations of different inositol phosphate (InsP) isomers (nmol/g DM) in the crop digesta (Mean values and pooled standard errors; ten pens per treatment with fifteen birds per pen)

\begin{tabular}{|c|c|c|c|c|c|}
\hline & $\mathrm{BD}$ & PhyA & PhyE1 & PhyE2 & Pooled SEM \\
\hline $\operatorname{lnsP}_{3}{ }^{*}$ & ND & $4268^{a}$ & $783^{b}$ & $845^{\mathrm{b}}$ & 214 \\
\hline Proportion of $\operatorname{InsP}_{3}$ in $\Sigma \operatorname{lnsP}_{3-5}$ & & $0.69^{a}$ & $0 \cdot 15^{b}$ & $0.13^{\mathrm{b}}$ & 0.018 \\
\hline $\operatorname{Ins}(1,2,4,6) \mathrm{P}_{4}$ & ND & ND & ND & ND & \\
\hline $\operatorname{lns}(1,2,3,4) \mathrm{P}_{4}$ & ND & ND & 170 & ND & $20 \cdot 8$ \\
\hline $\operatorname{lns}(1,2,5,6) \mathrm{P}_{4}$ & $141^{\mathrm{c}}$ & $922^{c}$ & $2708^{b}$ & $4505^{a}$ & 421 \\
\hline Proportion of $\Sigma \operatorname{lnsP}_{4}$ in $\Sigma \operatorname{lnsP}_{3-5}$ & $0.10^{c}$ & $0.14^{\mathrm{c}}$ & $0.57^{\mathrm{b}}$ & $0.74^{a}$ & 0.032 \\
\hline $\operatorname{lns}(1,2,3,4,6) \mathrm{P}_{5}$ & $116^{\mathrm{a}}$ & ND & $65^{\mathrm{b}}$ & ND & $5 \cdot 1$ \\
\hline $\operatorname{lns}(1,2,3,4,5) P_{5}$ & $388^{a, b}$ & $101^{\mathrm{c}}$ & $475^{a}$ & $355^{\mathrm{b}}$ & 23.0 \\
\hline $\operatorname{lns}(1,2,4,5,6) \mathrm{P}_{5}$ & $638^{\mathrm{b}}$ & $886^{a}$ & $371^{\mathrm{c}}$ & $241^{d}$ & $46 \cdot 2$ \\
\hline $\operatorname{Ins}(1,3,4,5,6) \mathrm{P}_{5}$ & 51 & ND & ND & ND & 8.6 \\
\hline Proportion of $\Sigma \operatorname{lns} P_{5}$ in $\Sigma \operatorname{lns} P_{3-5}$ & $0.90^{\mathrm{a}}$ & $0 \cdot 16^{\mathrm{c}}$ & $0.28^{\mathrm{b}}$ & $0.13^{c}$ & 0.037 \\
\hline $\operatorname{lnsP}_{6}$ & $14491^{a}$ & $5790^{d}$ & $10922^{b}$ & $8670^{c}$ & 720 \\
\hline
\end{tabular}

BD, basal diet; PhyA, BD supplemented with Aspergillus niger 3-phytase, Finase ${ }^{\circledR}$ P; PhyE1, BD supplemented with Escherichia coli 6-phytase, Quantum ${ }^{\circledR}$; PhyE2, BD supplemented with $E$. coli 6-phytase, Quantum ${ }^{\circledR} \mathrm{Blue}$; InsP ${ }_{3}$, myo-inositol trisphosphate; ND, not detected (the InsP isomer was not detectable in the majority of samples); InsP ${ }_{4}$, myoinositol tetrakisphosphate; Ins $\mathrm{P}_{5}$, myo-inositol pentakisphosphate; InsP $\mathrm{P}_{6}$, myo-inositol 1,2,3,4,5,6-hexakis (dihydrogen phosphate).

${ }^{a-d}$ Mean values in a row with unlike superscript letters were significantly different $(P \leq 0.05$; Fisher's protected least significant difference test). Mean separation was only computed if the overall $F$ test was significant.

* At least one out of the following $\operatorname{Ins} \mathrm{P}_{3}$ isomers: Ins $(1,4,5) \mathrm{P}_{3}, \operatorname{Ins}(1,2,6) \mathrm{P}_{3}, \operatorname{Ins}(2,4,5) \mathrm{P}_{3}, \operatorname{Ins}(1,3,4) \mathrm{P}_{3}, \operatorname{Ins}(1,4,6) \mathrm{P}_{3}$.

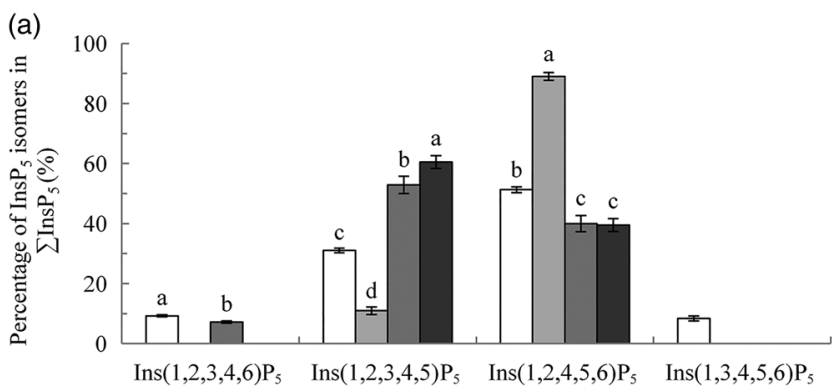

(b)

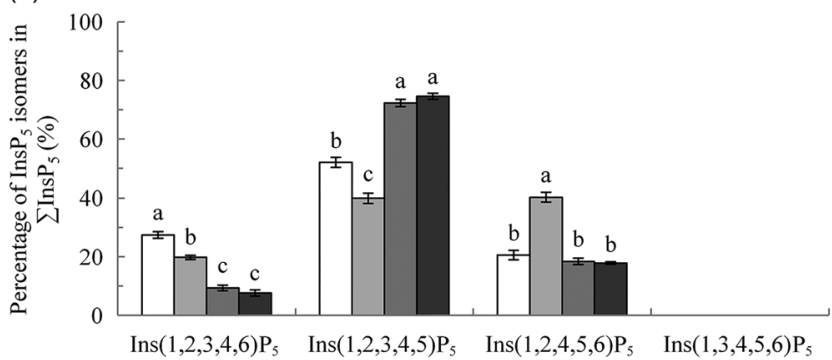

(c)

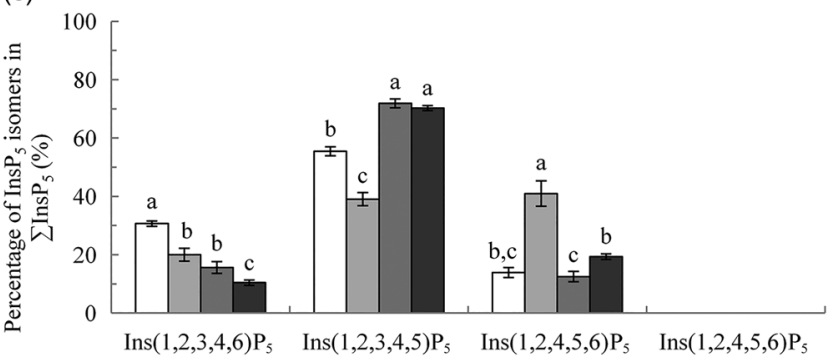

Fig. 1. Myo-inositol pentakisphosphate $\left(\operatorname{lns}_{5}\right)$ isomers in the crop $(A)$, duodenum/jejunum (B) and ileum (C), expressed as a percentage of $\sum \operatorname{lns} P_{5}$. Values are means, with their standard errors represented by vertical bars. ${ }^{a-d}$ Values with unlike letters within an $\operatorname{Ins}_{5}$ isomer were significantly different $(P \leq 0.05$; Fisher's protected least significant difference test). Mean separation was only computed if the overall $F$ test was significant. $\square$, Basal diet (BD); : $:$, BD supplemented with Aspergillus niger 3-phytase, Finase ${ }^{\circledR} \mathrm{P}$ (PhyA); 业, BD supplemented with Escherichia coli 6-phytase, Quantum ${ }^{\circledR}$ (PhyE1); supplemented with E. coli 6-phytase, Quantum ${ }^{\circledR}$ Blue (PhyE2). contrast, for PhyE1 and PhyE2, the percentage of Ins $(1,2,3,4,5) \mathrm{P}_{5}$ in $\sum$ Ins $\mathrm{P}_{5}$ was significantly higher, but the percentage of $\operatorname{Ins}(1,2,4,5,6) \mathrm{P}_{5}$ in $\sum \operatorname{Ins} \mathrm{P}_{5}$ was significantly lower compared with the two other treatments. Ins $(1,2,5,6) \mathrm{P}_{4}$ and Ins $\mathrm{P}_{3}$ also occurred in the crop in high concentrations for the phytase-containing treatments (Table 5). Ins $(1,2,5,6) \mathrm{P}_{4}$ appeared for the PhyE1 and PhyE2 treatment in significantly higher concentrations compared with the $\mathrm{BD}$ and PhyA $(P<$ $0 \cdot 01$ ) and as the only inositol tetrakisphosphate formed by PhyA. Ins $\mathrm{P}_{3}$ appeared in significantly higher concentrations for PhyA than PhyE1 and PhyE2 $(P<0 \cdot 01)$. The proportion of $\Sigma$ Ins $\mathrm{P}_{4}$ in $\Sigma \mathrm{InsP}_{3-5}$ was significantly higher for PhyE2 (74 \%) than PhyE1 (57\%) and PhyA $(14 \%)(P<0 \cdot 01)$, and that of $\mathrm{InsP}_{3}$ in $\Sigma$ Ins $\mathrm{P}_{3-5}$ was significantly higher for PhyA (69 \%) compared with PhyE1 (15\%) and PhyE2 $(13 \%)(P<0.01)$ in the crop. In the proventriculus/gizzard, the Ins $\mathrm{P}_{5}$ pattern of the phytase-containing treatments was similar to that of the crop except Ins $(1,2,3,4,6) \mathrm{P}_{5}$ was not seen in the proventriculus/gizzard (Table 6). Ins $(1,2,5,6) \mathrm{P}_{4}$ and $\mathrm{Ins}_{3}$ were detected in significantly lower concentrations for PhyA compared with PhyE1 and PhyE2 $(P<0.01$ for both). A higher proportion of $\Sigma \operatorname{InsP}_{5}$ in $\Sigma \operatorname{InsP}_{3-5}$ and a lower proportion of $\Sigma \operatorname{InsP}_{4}$ in $\Sigma \operatorname{Ins}_{3-5}$ were identified for PhyA compared with PhyE1 and PhyE2 $(P<0 \cdot 01)$.

In the segments of the small intestine, almost the same InsP isomers were detected in all treatments, except Ins $(1,2,5,6) \mathrm{P}_{4}$, which occurred only in the phytase treatments (Tables 7 and 8). In the duodenum/jejunum, Ins(1,2,3,4,6) $\mathrm{P}_{5}$ appeared for the first time for PhyA and PhyE2 and again appeared for PhyE1. Ins $(1,2,3,4) \mathrm{P}_{4}$ was the predominating Ins $\mathrm{P}_{4}$ isomer for all treatments. The concentrations of Ins $(1,2,3,4,5) \mathrm{P}_{5}$ in the duodenum/jejunum were similar for the $\mathrm{BD}$ and the PhyA, but significantly higher for the PhyE1 and PhyE2 treatments $(P<0.01)$ (Table 7). Ins $(1,2,4,5,6) \mathrm{P}_{5}$ was detected in significantly higher concentrations for the PhyA compared with the other treatments $(P<0 \cdot 01)$. For all phytase treatments, a significantly lower proportion of $\operatorname{Ins}(1,2,3,4,6) \mathrm{P}_{5}$ in $\Sigma \operatorname{Ins} \mathrm{P}_{5}$ was determined 
Table 6. Concentrations of different inositol phosphate (InsP) isomers (nmol/g DM) in the proventriculus/gizzard digesta (Mean values and pooled standard errors; ten pens per treatment with fifteen birds per pen)

\begin{tabular}{|c|c|c|c|c|c|}
\hline & $\mathrm{BD}$ & PhyA & PhyE1 & PhyE2 & Pooled SEM \\
\hline $\operatorname{lnsP}_{3}^{*}$ & ND & $105^{\mathrm{c}}$ & $348^{b}$ & $517^{a}$ & $54 \cdot 2$ \\
\hline Proportion of $\operatorname{lnsP}_{3}$ in $\Sigma \operatorname{lns} P_{3-5}$ & & $0 \cdot 10$ & 0.09 & 0.11 & 0.012 \\
\hline $\operatorname{Ins}(1,2,4,6) \mathrm{P}_{4}$ & ND & ND & ND & ND & \\
\hline $\operatorname{lns}(1,2,3,4) \mathrm{P}_{4}$ & ND & ND & $<\mathrm{LOQ}$ & ND & \\
\hline Ins $(1,2,5,6) \mathrm{P}_{4}$ & ND & $254^{\mathrm{c}}$ & $2457^{b}$ & $3537^{a}$ & 211 \\
\hline Proportion of $\Sigma \operatorname{lnsP}_{4}$ in $\Sigma \operatorname{lnsP}_{3-5}$ & & $0.22^{\mathrm{c}}$ & $0.67^{\mathrm{b}}$ & $0.79^{\mathrm{a}}$ & 0.017 \\
\hline $\operatorname{lns}(1,2,3,4,6) \mathrm{P}_{5}$ & ND & ND & ND & ND & \\
\hline $\operatorname{lns}(1,2,3,4,5) P_{5}$ & $92^{c}$ & $107^{c}$ & $659^{a}$ & $295^{\mathrm{b}}$ & 30.6 \\
\hline $\operatorname{lns}(1,2,4,5,6) \mathrm{P}_{5}$ & $188^{\mathrm{b}}$ & $618^{a}$ & $155^{\mathrm{b}}$ & $80^{c}$ & $28 \cdot 0$ \\
\hline $\operatorname{Ins}(1,3,4,5,6) \mathrm{P}_{5}$ & ND & ND & ND & ND & \\
\hline Proportion of $\Sigma \operatorname{lns} P_{5}$ in $\Sigma \operatorname{lnsP}_{3-5}$ & $1.00^{\mathrm{a}}$ & $0.68^{b}$ & $0.24^{c}$ & $0.09^{d}$ & 0.020 \\
\hline $\operatorname{lnsP}_{6}$ & $6877^{\mathrm{a}}$ & $4968^{b}$ & $2219^{c}$ & $739^{d}$ & 196 \\
\hline
\end{tabular}

BD, basal diet; PhyA, BD supplemented with Aspergillus niger 3-phytase, Finase ${ }^{\circledR}$ P; PhyE1, BD supplemented with Escherichia coli 6-phytase, Quantum ${ }^{\circledR}$; PhyE2, BD supplemented with E. coli 6-phytase, Quantum ${ }^{\circledR}$ Blue; InsP $\mathrm{P}_{3}$, myo-inositol trisphosphate; ND, not detected (the InsP isomer was not detectable in the majority of samples); Ins $\mathrm{P}_{4}$, myoinositol tetrakisphosphate; LOQ, limit of quantification (the InsP isomer was not quantifiable in the majority of samples); Ins $\mathrm{P}_{5}$, myo-inositol pentakisphosphate; Ins: $\mathrm{P}_{6}$, myo-inositol 1,2,3,4,5,6-hexakis (dihydrogen phosphate).

${ }^{a-d}$ Mean values in a row with unlike superscript letters were significantly different $(P \leq 0.05$; Fisher's protected least significant difference test). Mean separation was only computed if the overall $F$ test was significant.

${ }^{*}$ At least one out of the following $\operatorname{Ins} P_{3}$ isomers: Ins $(1,4,5) P_{3}, \operatorname{Ins}(1,2,6) P_{3}, \operatorname{lns}(2,4,5) P_{3}, \operatorname{Ins}(1,3,4) P_{3}, \operatorname{lns}(1,4,6) P_{3}$

compared with the BD in the duodenum/jejunum (Fig. 1 (B)) and lower ileum (Fig. 1 (C)) $(P<0 \cdot 01)$. In the lower ileum, the significant difference in Ins $(1,2,4,5,6) \mathrm{P}_{5}$ concentrations persisted $(P<0 \cdot 01)$ whereas the difference in Ins $(1,2,3,4,5) \mathrm{P}_{5}$ concentrations lost significance (Table 8). Ins $P_{3}$ was not detectable in any of the treatments in the small intestine.

In the caeca, the differences in InsP patterns between the phytase-containing diets and the $\mathrm{BD}$ were less distinct than in other sections. Concentrations of Ins $(1,2,3,4,6) \mathrm{P}_{5}$ and Ins $(1,2,3,4) \mathrm{P}_{4}$ were lower $(P<0 \cdot 01)$ and concentrations of $\operatorname{Ins}_{3}(P=0 \cdot 03)$ and $\operatorname{Ins}(1,2,5,6) \mathrm{P}_{4}(P=0 \cdot 04)$ partially higher when phytases were supplemented, especially for PhyE2 (Table 9). The specific InsP isomers of the supplemented phytases were still present in the caeca. The predominating Ins $\mathrm{P}_{5}$ isomer was $\operatorname{Ins}(1,2,3,4,5) \mathrm{P}_{5}$ for all phytase treatments. For the PhyA treatment, significantly higher concentrations of Ins
$(1,2,4,5,6) \mathrm{P}_{5}$ were measured compared with the other treatments $(P<0 \cdot 01)$.

\section{Discussion \\ Myo-inositol 1,2,3,4,5,6-hexakis (dihydrogen phosphate) hydrolysis and net absorption of phosphorus}

In agreement with previous studies that used low-Ca and low-P diets ${ }^{(11-13)}$ we found a high rate of InsP $_{6}$ hydrolysis $(76 \%)$ and $\mathrm{P}$ net absorption (57\%) in the lower ileum. This raises the question of the origin of phytase responsible for this hydrolysis. We found that without supplemented phytase, the majority of Ins $\mathrm{P}_{6}$ hydrolysis occurred by the end of the duodenum/jejunum, but hydrolysis still continued in the ileum and caeca. In the small intestine of broilers, the greatest endogenous mucosa phytase activity was found in the

Table 7. Concentrations of different inositol phosphate (InsP) isomers (nmol/g DM) in the duodenal/jejunal digesta (Mean values and pooled standard errors; ten pens per treatment with fifteen birds per pen)

\begin{tabular}{|c|c|c|c|c|c|}
\hline & $\mathrm{BD}$ & PhyA & PhyE1 & PhyE2 & Pooled SEM \\
\hline $\operatorname{lnsP}_{3}^{*}$ & ND & ND & ND & ND & \\
\hline Ins $(1,2,4,6) \mathrm{P}_{4}$ & ND & ND & ND & ND & \\
\hline $\operatorname{lns}(1,2,3,4) \mathrm{P}_{4}$ & 355 & $<\mathrm{LOQ}$ & 303 & 265 & $75 \cdot 1$ \\
\hline $\operatorname{lns}(1,2,5,6) \mathrm{P}_{4}$ & ND & $<L O Q$ & $123^{b}$ & $234^{\mathrm{a}}$ & 44.9 \\
\hline Proportion of $\Sigma \operatorname{lnsP}_{4}$ in $\Sigma \operatorname{lnsP}_{3-5}$ & 0.28 & & 0.26 & 0.27 & 0.025 \\
\hline $\operatorname{lns}(1,2,3,4,6) P_{5}$ & $207^{\mathrm{a}}$ & $184^{\mathrm{a}}$ & $110^{\mathrm{b}}$ & $99^{b}$ & $16 \cdot 7$ \\
\hline $\operatorname{lns}(1,2,3,4,5) \mathrm{P}_{5}$ & $399^{b}$ & $376^{\mathrm{b}}$ & $864^{a}$ & $957^{\mathrm{a}}$ & 111 \\
\hline $\operatorname{lns}(1,2,4,5,6) \mathrm{P}_{5}$ & $148^{\mathrm{C}}$ & $379^{a}$ & $214^{\mathrm{b}, \mathrm{c}}$ & $232^{\mathrm{b}}$ & $31 \cdot 7$ \\
\hline $\operatorname{lns}(1,3,4,5,6) P_{5}$ & ND & ND & ND & ND & \\
\hline Proportion of $\Sigma \operatorname{lnsP}_{5}$ in $\Sigma \operatorname{lnsP}_{3-5}$ & $0.72^{\mathrm{b}}$ & $1.00^{\mathrm{a}}$ & $0.74^{\mathrm{b}}$ & $0.73^{\mathrm{b}}$ & 0.022 \\
\hline $\operatorname{lns}_{6}$ & 13392 & 12664 & 11812 & 10701 & 1076 \\
\hline
\end{tabular}

BD, basal diet; PhyA, BD supplemented with Aspergillus niger 3-phytase, Finase ${ }^{\circledR}$ P; PhyE1, BD supplemented with Escherichia coli 6-phytase, Quantum ${ }^{\circledR}$; PhyE2, BD supplemented with $E$. coli 6-phytase, Quantum ${ }^{\circledR}$ Blue; Ins $\mathrm{P}_{3}$, myo-inositol trisphosphate; ND, not detected (the Ins $\mathrm{P}$ isomer was not detectable in the majority of samples); InsP $\mathrm{P}_{4}$, myoinositol tetrakisphosphate; $\mathrm{LOQ}$, limit of quantification (the InsP isomer was not quantifiable in the majority of samples); Ins $\mathrm{P}_{5}$, myo-inositol pentakisphosphate; Ins $\mathrm{P}_{6}$, myo-inositol 1,2,3,4,5,6-hexakis (dihydrogen phosphate).

a,b,c Mean values in a row with unlike superscript letters were significantly different $(P \leq 0.05$; Fisher's protected least significant difference test). Mean separation was only computed if the overall $F$ test was significant.

${ }^{*}$ At least one out of the following $\operatorname{Ins} \mathrm{P}_{3}$ isomers: $\operatorname{Ins}(1,4,5) \mathrm{P}_{3}, \operatorname{Ins}(1,2,6) \mathrm{P}_{3}, \operatorname{Ins}(2,4,5) \mathrm{P}_{3}, \operatorname{Ins}(1,3,4) \mathrm{P}_{3}, \operatorname{Ins}(1,4,6) \mathrm{P}_{3}$. 
Table 8. Concentrations of different inositol phosphate (InsP) isomers ( $\mathrm{nmol} / \mathrm{g} \mathrm{DM})$ in the digesta of the lower ileum (Mean values and pooled standard errors; ten pens per treatment with fifteen birds per pen)

\begin{tabular}{|c|c|c|c|c|c|}
\hline & $\mathrm{BD}$ & PhyA & PhyE1 & PhyE2 & Pooled SEM \\
\hline $\operatorname{lns} P_{3}{ }^{*}$ & ND & ND & ND & ND & \\
\hline $\operatorname{lns}(1,2,4,6) \mathrm{P}_{4}$ & 121 & ND & $<L O Q$ & $<L O Q$ & 30.5 \\
\hline $\operatorname{lns}(1,2,3,4) \mathrm{P}_{4}$ & 309 & 248 & 282 & 216 & 69.3 \\
\hline $\operatorname{lns}(1,2,5,6) \mathrm{P}_{4}$ & ND & 275 & 177 & 192 & 61.4 \\
\hline Proportion of $\Sigma \operatorname{lnsP}_{4}$ in $\Sigma \operatorname{lnsP}_{3-5}$ & 0.34 & 0.31 & 0.31 & 0.31 & 0.036 \\
\hline $\operatorname{Ins}(1,2,3,4,6) P_{5}$ & $231^{a}$ & $209^{a}$ & $149^{a, b}$ & $106^{\mathrm{b}}$ & $36 \cdot 0$ \\
\hline $\operatorname{lns}(1,2,3,4,5) \mathrm{P}_{5}$ & 422 & 410 & 776 & 735 & 156 \\
\hline $\operatorname{lns}(1,2,4,5,6) \mathrm{P}_{5}$ & $110^{\mathrm{b}}$ & $463^{a}$ & $163^{b}$ & $195^{\mathrm{b}}$ & 51.5 \\
\hline $\operatorname{lns}(1,3,4,5,6) P_{5}$ & ND & ND & ND & ND & \\
\hline Proportion of $\Sigma \operatorname{lns} P_{5}$ in $\Sigma \operatorname{lns} P_{3-5}$ & 0.66 & 0.69 & 0.69 & 0.69 & 0.036 \\
\hline $\operatorname{lns}_{6}$ & 11575 & 12348 & 9965 & 8913 & 2089 \\
\hline
\end{tabular}

BD, basal diet; PhyA, BD supplemented with Aspergillus niger 3-phytase, Finase ${ }^{\circledR}$ P; PhyE1, BD supplemented with Escherichia coli 6-phytase, Quantum ${ }^{\circledR}$; PhyE2, BD supplemented with E. coli 6-phytase, Quantum ${ }^{\circledR}$ Blue; Ins $\mathrm{P}_{3}$, myo-inositol trisphosphate; ND, not detected (the InsP isomer was not detectable in the majority of samples); Ins $\mathrm{P}_{4}$, myo-

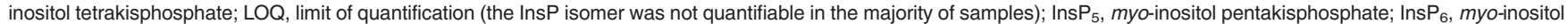
1,2,3,4,5,6-hexakis (dihydrogen phosphate).

a,b Mean values in a row with unlike superscript letters were significantly different $(P \leq 0.05$; Fisher's protected least significant difference test). Mean separation was only computed if the overall $F$ test was significant.

${ }^{*}$ At least one out of the following $\operatorname{Ins} \mathrm{P}_{3}$ isomers: Ins $(1,4,5) \mathrm{P}_{3}, \operatorname{Ins}(1,2,6) \mathrm{P}_{3}, \operatorname{Ins}(2,4,5) \mathrm{P}_{3}, \operatorname{Ins}(1,3,4) \mathrm{P}_{3}, \operatorname{lns}(1,4,6) \mathrm{P}_{3}$.

duodenum ${ }^{(8,10)}$. Phytate-degrading activity has also been reported for different lactic acid bacteria isolated from chicken intestine ${ }^{(31)}$. Thus, intestinal $\operatorname{Ins}_{6}$ hydrolysis was the result of a combination of endogenous and microbiota phytase, with as-yet-unknown contributions from each source. When phytase activity in different segments of the digestive tract was compared, the highest activity was found in the caeca ${ }^{(32)}$ and Kerr et al. ${ }^{(14)}$ detected higher concentrations of $\operatorname{InsP}_{6}$ in the caeca of gnotobiotic compared with conventional broilers. In line with this observation, caecal Ins $\mathrm{P}_{6}$ hydrolysis determined in the present study was greater than $90 \%$. It should be noted that retrograde movement of digesta and micro-organisms has been described for all segments of the digestive tract in broilers ${ }^{(33)}$ and it cannot be ruled out that this affected concentrations of InsP isomers, $\mathrm{P}$ and $\mathrm{Ti}$ anterior to the caeca.

With supplemented phytase, the crop and the proventriculus/ gizzard were the main sites of $\mathrm{Ins}_{6}$ hydrolysis in the present study. The differences found between the supplemented phytases in these segments might be related to differences in enzyme kinetics, $\mathrm{pH}$ or resistance against gastrointestinal proteases. A higher temperature optimum was reported for $E$. coli compared with Aspergillus phytases ${ }^{(34,35)}$. At approximate body temperature $\left(42^{\circ} \mathrm{C}\right)$, Aspergillus phytases show an activity of $85 \%$ of the maximum whereas the activity of some E. coli phytases is reduced to $60 \%$ of the in vitro analysed maximum $^{(34)}$. Furthermore, E. coli phytases are more resistant than Aspergillus phytases against pepsin and pancreatin and show a higher activity at $\mathrm{pH} 3$, which is close to the $\mathrm{pH}$ in the proventriculus/gizzard ${ }^{(35-37)}$. This might explain why the differences between phytases noted in the crop disappeared in the duodenum/jejunum. Moreover, a residual activity of 93 and $60 \%$ has been found for an E. coli and an Aspergillus phytase, respectively, after incubation in digesta of the proventriculus ${ }^{(35)}$.

Table 9. Concentrations of different inositol phosphate (InsP) isomers (nmol/g DM) in the caecal digesta (Mean values and pooled standard errors; ten pens per treatment with fifteen birds per pen)

\begin{tabular}{|c|c|c|c|c|c|}
\hline & BD & PhyA & PhyE1 & PhyE2 & Pooled SEM \\
\hline $\operatorname{lnsP}_{3}{ }^{*}$ & $217^{\mathrm{b}}$ & $275^{\mathrm{b}}$ & $355^{a, b}$ & $470^{\mathrm{a}}$ & 59.4 \\
\hline Proportion of $\operatorname{InsP}_{3}$ in $\Sigma \operatorname{InsP}_{3-5}$ & $0.09^{b}$ & $0.13^{\mathrm{b}}$ & $0.19^{b}$ & $0.30^{\mathrm{a}}$ & 0.020 \\
\hline $\operatorname{lns}(1,2,4,6) \mathrm{P}_{4}$ & ND & ND & ND & ND & \\
\hline Ins $(1,2,3,4) \mathrm{P}_{4}$ & $750^{\mathrm{a}}$ & $484^{\mathrm{b}}$ & $422^{b}$ & $284^{\mathrm{b}}$ & $86 \cdot 1$ \\
\hline Ins $(1,2,5,6) \mathrm{P}_{4}$ & $<\mathrm{LOQ}$ & $309^{a}$ & $190^{\mathrm{b}}$ & $318^{a}$ & 38.9 \\
\hline Proportion of $\Sigma \operatorname{lnsP}_{4}$ in $\Sigma \operatorname{lnsP}_{3-5}$ & $0.34^{\mathrm{b}}$ & $0.41^{\mathrm{a}}$ & $0.36^{\mathrm{b}}$ & $0.39^{a, b}$ & 0.015 \\
\hline $\operatorname{lns}(1,2,3,4,6) \mathrm{P}_{5}$ & $365^{\mathrm{a}}$ & $186^{\mathrm{b}}$ & $88^{\mathrm{b}}$ & ND & 43.8 \\
\hline $\operatorname{lns}(1,2,3,4,5) \mathrm{P}_{5}$ & $578^{\mathrm{a}}$ & $324^{\mathrm{b}}$ & $436^{a, b}$ & $308^{b}$ & 63.7 \\
\hline $\operatorname{lns}(1,2,4,5,6) \mathrm{P}_{5}$ & $119^{b}$ & $302^{\mathrm{a}}$ & $96^{\mathrm{b}}$ & $82^{\mathrm{b}}$ & $18 \cdot 8$ \\
\hline $\operatorname{Ins}(1,3,4,5,6) P_{5}$ & 75 & 85 & 86 & 85 & 7.5 \\
\hline Proportion of $\Sigma \operatorname{lnsP}_{5}$ in $\Sigma \operatorname{lnsP}_{3-5}$ & $0.57^{\mathrm{a}}$ & $0.47^{\mathrm{b}}$ & $0.45^{\mathrm{b}}$ & $0.31^{c}$ & 0.023 \\
\hline $\operatorname{lns}_{6}$ & $6751^{a}$ & $4494^{b}$ & $3648^{b, c}$ & $2255^{c}$ & 544 \\
\hline
\end{tabular}

BD, basal diet; PhyA, BD supplemented with Aspergillus niger 3-phytase, Finase ${ }^{\circledR} \mathrm{P}$; PhyE1, BD supplemented with Escherichia coli 6-phytase, Quantum ${ }^{\circledR}$; PhyE2, BD supplemented with $E$. coli 6-phytase, Quantum ${ }^{\circledR}$ Blue; InsP $\mathrm{P}_{3}$, myo-inositol trisphosphate; Ins $\mathrm{P}_{4}$, myo-inositol tetrakisphosphate; ND, not detected (the InsP isomer was not detectable in the majority of samples); LOQ, limit of quantification (the InsP isomer was not quantifiable in the majority of samples); Ins $\mathrm{P}_{5}$, myo-inositol pentakisphosphate; Ins $\mathrm{P}_{6}$, myo-inositol 1,2,3,4,5,6-hexakis (dihydrogen phosphate).

a,b,c Mean values in a row with unlike superscript letters were significantly different $(P \leq 0.05$; Fisher's protected least significant difference test). Mean separation was only computed if the overall $F$ test was significant.

${ }^{*}$ At least one out of the following $\operatorname{Ins} P_{3}$ isomers: Ins $(1,4,5) P_{3}, \ln (1,2,6) P_{3}, \operatorname{lns}(2,4,5) P_{3}, \operatorname{lns}(1,3,4) P_{3}, \operatorname{lns}(1,4,6) P_{3}$. 


\section{Appearance of inositol phosphate isomers: basal diet}

Past experiments in poultry have focused on the analysis of Ins $\mathrm{P}_{6}$ and rarely considered clarification of the location of Ins $\mathrm{P}_{6}$ hydrolysis ${ }^{(14,32,38)}$. A few studies have investigated the sum of $\operatorname{InsP}_{5}, \operatorname{InsP}_{4}$ and $\mathrm{InsP}_{3}$ isomers in digesta samples of poultry, without differentiation among positional isomers ${ }^{(39-41)}$. The authors are not aware of any published study investigating positional InsP isomers in the digestive tract of broilers, which led us to making this one of our objectives.

When the $\mathrm{BD}$ was fed, the dominating $\mathrm{Ins}_{5}$ isomers found in the crop were $\operatorname{Ins}(1,2,4,5,6) \mathrm{P}_{5}$ and $\operatorname{Ins}(1,2,3,4,5) \mathrm{P}_{5}$. Ins $(1,2,3,4,6) \mathrm{P}_{5}$ and $\operatorname{Ins}(1,3,4,5,6) \mathrm{P}_{5}$ that occurred in concentrations close to the limit of detection may have originated from the diet (Table 1). The changing pattern of Ins $\mathrm{P}_{5}$ isomers (Fig. $1(\mathrm{~A})$ ) in the crop compared with the diet affirm InsP 6 hydrolysis in the crop, as does the additional occurrence of Ins $\mathrm{P}_{4}$. The appearance of $\operatorname{Ins}(1,2,4,5,6) \mathrm{P}_{5}$ might have been caused by residual intrinsic soyabean phytase, which is a 3-phytase, that withstood exposure to heat in the desolventiser-toaster and was below the limit of detection in the feed. However, this could also have been caused by microbial phytases because 3-phytases are primarily found in fungi (A. niger, A. terreus, A. fumigatus, Neurospora crassa), yeasts (Saccharomyces castellii, Saccharomyces cerevisiae) and bacteria (Selenomonas ruminantium, Selenomonas lacticifex, Megasphaera elsdenii, Klebsiella terrigena, Pantoea agglomerans, Pseudomonas syringae, Bacillus subtilis, Bacillus amyloliquefaciens). Phytases of plant origin are primarily classified as 4-/6-phytases but 6-phytases were also found for specific bacteria such as E. coli, Peniophora lycii and Bifidobacterium pseudocatenulatum $^{(7,42,43)}$. Therefore, it remains open whether in the present study Ins $(1,2,3,4,5) \mathrm{P}_{5}$ was formed by plant or microbiota phytase. Ins $(1,2,5,6) \mathrm{P}_{4}$ (perhaps co-eluted with Ins $\left.(2,3,4,5) \mathrm{P}_{4}\right)$ measured in the crop could have been formed by 3- or 6-phytases ${ }^{(5,7)}$. A formation by other phosphatases which further degraded Ins $(1,2,4,5,6) \mathrm{P}_{5}$ or $\operatorname{Ins}(1,2,3,4,5) \mathrm{P}_{5}$ to Ins $(1,2,5,6) \mathrm{P}_{4}$ also is possible.

The fact that there was so little Ins $_{5}$ in the proventriculus/ gizzard suggests that when no phytase is added there is very little Ins $\mathrm{P}_{6}$ hydrolysis in that acid environment. Some remaining intrinsic plant phytase may rapidly be inactivated at low $\mathrm{pH}$ values and in the presence of pepsin and pancreatin ${ }^{(44-47)}$. The lack of Ins $\mathrm{P}_{3-4}$ isomers and the dominance of $\mathrm{Ins}_{5}$ isomers in the proventriculus/gizzard further indicate that $\mathrm{Ins}_{5}$ hydrolysis is less rapidly advanced. However, InsP and their complexes are soluble under acidic conditions and mineral chelates of lower InsPs are more soluble. Hence fast breakdown of $\mathrm{Ins}_{3-4}$ also could have happened in the proventriculus/gizzard.

Following passage through the acid phase of the proventriculus/gizzard, a higher accessibility of phytate in the posterior segments can be assumed. In the duodenum/jejunum, a greater range of InsP isomers compared with those found in the stomach was found for the BD treatment, showing intense hydrolysis of Ins $\mathrm{P}_{6}$ in this segment. This increase probably was the result of substrate-induced Ins $\mathrm{P}_{6}$ hydrolysis by microbiota or endogenous mucosa phytase. Phytate-induced phytase production was reported for several bacteria ${ }^{(48-50)}$. The results of Schlemmer et al. ${ }^{(16)}$ showed substrate dependence of microbiota phytase activity in the colon of pigs. For mucosal phytase, increased activity with dietary phytic acid was also reported in rats ${ }^{(51)}$. In addition to an alteration of $\mathrm{InsP}_{6}$ hydrolysis and diversity of InsP isomers, the InsP pattern changed between the anterior and intestinal segments of the digestive tract (Fig. 1). This change in InsP pattern suggests the involvement of phosphatases of different origin in different segments, with 3- and 6-phytases dominating in the crop and 6- and 5-phytases dominating in the intestinal segments. Ins $(1,2,3,4,5) \mathrm{P}_{5}$ can be formed by bacterial 6-phytase of the intestinal microbiota, for example, an E. coli 6-phytase. Ins $(1,2,3,4) \mathrm{P}_{4}$ first appeared in the duodenum/jejunum and was the dominating $\mathrm{Ins}_{4}$ isomer in all intestinal segments when the BD was fed. It might have been a hydrolysis product of a 5-phytase because the majority of phytases continue dephosphorylation adjacent to a free hydroxyl group. Ins $(1,2,3,4) \mathrm{P}_{4}$ (perhaps co-eluted with $\left.\operatorname{Ins}(1,2,3,6) \mathrm{P}_{4}\right)$ was also characterised as a hydrolysis product of a 5-phytase in lily pollen and Selenomonas ruminantium subsp. lactilytica ${ }^{(52,53)}$. However, as Ins $(1,2,3,4) \mathrm{P}_{4}$ was also detected as a minor hydrolysis product of specific 6-phytases, it principally could have been formed by both 5- and 6-phytases. In addition, the involvement of other phosphatases which further degraded $\mathrm{Ins}_{5}$ cannot be ruled out. Because 5-phytase is described only for Selenomonas ruminantium subsp. lactilytica ${ }^{(53)}$, lily pollen and Bifidobacterium pseudocatenulatum $^{(43)}$, its origin in the intestine of broilers was unexpected. Human gut-isolated Bifidobacterium pseudocatenulatum initiates $\mathrm{Ins}_{6}$ hydrolysis at the C- 6 and C- 5 position of the myo-inositol ring and proceeds via $\operatorname{Ins}(1,2,3,4) \mathrm{P}_{4}^{(43)}$, but the authors are not aware of any study that found this species of Bifidobacterium in broilers.

For the caeca, the broad pattern of InsP isomers is an indication of a highly diverse microbial population likewise producing several phytate-degrading enzymes. From bacteria occurring in the chicken digestive tract, phytate-degrading activity has been described for Lactobacillus spp. ${ }^{(31)}$, Enterobacter spp. ${ }^{(54)}$, E. coli ${ }^{(7)}$, Klebsiella pneumoniae ${ }^{(55)}$, Bacillus spp. ${ }^{(56)}$, Bifidobacterium spp. ${ }^{(57)}$ and Pseudomonas aeruginosa ${ }^{(58)}$. Differences between the InsP pattern of the intestinal segments might be caused by the differing microbial community composition as described by Lu et al. ${ }^{(59)}$ and coupled with the variations in activity of the endogenous phytase. Ins $(1,3,4,5,6)$ $\mathrm{P}_{5}$, which appeared in the caeca, indicates the activity of a phosphatase in the caeca that initiates hydrolysis at the C-2 position of the inositol ring. If this was not undegraded Ins $(1,3,4,5,6) \mathrm{P}_{5}$ from the feed then this finding contradicts the general assumption that phytate-degrading enzymes are unable to cleave the axial phosphate group of the myo-inositol ring.

\section{Appearance of inositol phosphate isomers: phytase} treatments

The second objective of the present study was to investigate the Ins $\mathrm{P}_{6}$ degradation pattern of different phytase supplements and their effectiveness in releasing phosphate in different 
segments of the digestive tract. For the PhyA treatment, Ins $(1,2,4,5,6) \mathrm{P}_{5}$ was the predominant $\mathrm{Ins}_{5}$ isomer whereas Ins $(1,2,3,4,5) \mathrm{P}_{5}$ was predominant for the PhyE1 and PhyE2 treatments. This shows, for the first time, that in the crop of broilers the patterns are very similar to the in vitro pattern of hydrolysis of these 3- and 6-phytases, initiating Ins $\mathrm{P}_{6}$ hydrolysis at the D-3 (L-1) and D-6 (L-4) positions of the inositol ring ${ }^{(5,7)}$. Ins $(1,2,5,6) \mathrm{P}_{4}$ (perhaps co-eluted with $\operatorname{Ins}(2,3,4,5)$ $\mathrm{P}_{4}$ ) and $\mathrm{Ins}_{3}$, both of which were present in high concentrations for the phytase treatments, are the two other main hydrolysis products of the three phytases. This pattern conforms with in vitro results that showed $\mathrm{D}-\operatorname{Ins}(2,3,4,5) \mathrm{P}_{4}$ as a hydrolysis product of $E$. coli and $D-\operatorname{Ins}(1,2,5,6) \mathrm{P}_{4}$ of Aspergillus phytase ${ }^{(5,7)}$. The proportion of $\Sigma \mathrm{InsP}_{4}$ in $\Sigma \mathrm{InsP}_{3-5}$ was higher for PhyE1 and PhyE2 compared with PhyA whereas the proportion of $\operatorname{InsP}_{3}$ in $\Sigma \mathrm{Ins}_{3-5}$ was higher for PhyA in the crop. Accumulation of myo-inositol tris- and bisphosphates following hydrolysis by $A$. niger phytase has already been shown in vitro ${ }^{(60)}$. In contrast, a fast progression from Ins $\mathrm{P}_{5}$ to $\mathrm{InsP}_{4}$ is expected for E. coli, but $\mathrm{InsP}_{4}$ accumulated. This result corresponds to in vitro findings in which $\mathrm{InsP}_{4}$ accumulated during Ins $\mathrm{P}_{6}$ hydrolysis by E. coli phytase and was later slowly hydrolysed to $\operatorname{Ins}_{3}^{(6)}$. Because the lower-molecularweight esters of InsPs have a lower mineral-binding strength than $\operatorname{Ins}_{6}$ or $\operatorname{Ins}_{5}{ }^{(61)}$, the solubility of these esters in the small intestine will be improved, allowing access to them by the endogenous phytase/phosphatases ${ }^{(62)}$.

In the duodenum/jejunum and to some extent also in the ileum, the $\operatorname{Ins}_{5}$ and $\mathrm{InsP}_{4}$ isomers specifically formed by the respective supplemented phytases were present in higher concentrations compared with both the BD and the other phytase treatments. Thus, further activity of the enzymes can be assumed in these intestinal segments. However, the proportion of Ins $(1,2,3,4,6) \mathrm{P}_{5}$ in $\Sigma \mathrm{Ins}_{5}$ was significantly lower, and concentrations of Ins $(1,2,3,4) \mathrm{P}_{4}$ tended to be lower for the phytase treatments compared with the $\mathrm{BD}$ treatment in the duodenum/jejunum and lower ileum. Supplementation of phytase tends to reduce lactic acid bacterial count and significantly reduce E. coli count in the ileal digesta of broilers ${ }^{(63)}$, and, as mentioned earlier, both bacterial groups were suspected to be involved in phytate degradation. Aydin et al. ${ }^{(63)}$ speculated that the decrease is related to a possible reduction in the quantity of substrate available to the intestinal microbiota. If there was a reduction of lactic acid bacteria (for example, Bifidobacteria) this might explain the decrease in 5 -phytase activity for all phytase-containing treatments whereas a reduction of E. coli bacteria might explain the decrease in 6-phytase activity for PhyA. Furthermore, a reduction in intestinal mucosal phytase activity has been reported when chickens were supplemented with phytase ${ }^{(10)}$. Thus, a decrease in activity of endogenous mucosal phytase might also have contributed to different InsP pattern between the phytase and the BD treatments in the small intestine. In the lower ileum, the significant differences between treatments in Ins $(1,2,4,5,6) \mathrm{P}_{5}$ concentration persisted, but the differences in $\operatorname{Ins}(1,2,3,4,5) \mathrm{P}_{5}$ concentration did not. An explanation could be that the activity of supplemented phytases was significantly reduced at this point due to increasing $\mathrm{pH}$ and/or proteolytic degradation.
Igbasan et al. ${ }^{(35)}$ detected a residual activity of 60 and $55 \%$ for an Aspergillus and 87 and $80 \%$ for an E. coli phytase in the jejunal and ileal digesta, respectively. Intestinal phosphatases might continue to hydrolyse $\mathrm{Ins}_{3-5}$ isomers formed by the supplemented PhyE1 and PhyE2, but InsP $\mathrm{P}_{5}$ isomers formed by PhyA seemed to be less degradable by intestinal phosphatases. In this regard, $\mathrm{Yu}$ et al. ${ }^{(64)}$ showed that Ins $(1,2,4,5,6) \mathrm{P}_{5}$ was a more potent aggregator of protein at low $\mathrm{pH}$ compared with Ins $(1,2,3,4,5) \mathrm{P}_{5}$ which probably would reduce susceptibility of this isomer to phosphatase activity in the intestine.

\section{Conclusions}

We conclude that broilers and their microbiota have a high capacity to hydrolyse $\mathrm{Ins}_{6}$ in the intestine. The differentiation between $\mathrm{Ins}_{6}$ hydrolysis products of endogenous or microbiota phytases and their contribution to $\mathrm{Ins}_{6} \mathrm{P}_{6}$ hdrolysis in different segments still requires experimental work. Phytase supplements are more effective in the anterior than in the intestinal segments of the digestive tract, supporting in vitro properties. The main $\mathrm{Ins}_{6}$ degradation products of Aspergillus and E. coli phytases as determined from in vitro studies are also formed in the crop and proventriculus/gizzard of broilers. Differences in $\mathrm{InsP}_{6}$ hydrolysis between PhyE1 and PhyE2 compared with PhyA existing in the crop disappeared until the ileum. Ins $\mathrm{P}_{4}$ accumulated in the crop when PhyE1 and PhyE2 were used. However, InsP 3 accumulated when PhyA was used. It became apparent that the hydrolytic cleavage of the first phosphate group is not the only limiting step in phytate degradation in broilers.

\section{Acknowledgements}

The present study was supported by the Ministerium für Wissenschaft, Forschung und Kunst Baden-Württemberg (through a doctoral fellowship for E. Z.).

We would like to thank J. Boguhn for her assistance in trial planning and implementation.

The authors' contributions are as follows: E. Z. designed and performed the experiments, conducted parts of the chemical analysis, analysed data and drafted the manuscript. M. S. established and optimised the high-performance ion chromatography method and contributed to data presentation and interpretation. I. K. contributed to experimental design and data interpretation. M. R. contributed to all stages of the work, especially in the design, critical reflection on and interpretation of results, and preparation of the manuscript. All authors were involved in the discussion of the results and in editing of the manuscript.

The authors declare that there are no conflicts of interest.

\section{References}

1. Greiner R \& Konietzny U (2006) Phytase for food application. Food Technol Biotech 44, 125-140.

2. Cosgrove DJ (1970) Inositol phosphate phosphatases of microbiological origin. Inositol phosphate intermediates in the dephosphorylation of the hexaphosphates of myo-inositol, scyllo-inositol, and 
D-chiro-inositol by a bacterial (Pseudomonas sp.) phytase. Aust J Biol Sci 23, 1207-1220.

3. Skoglund E, Näsi M \& Sandberg AS (1998) Phytate hydrolysis in pigs fed a barley-rapeseed meal diet treated with Aspergillus niger phytase or steeped with whey. Can J Anim Sci 78, 175-180.

4. Dvořáková J, Kopecký J, Havlíček V, et al. (2000) Formation of myo-inositol phosphates by Aspergillus niger 3-phytase. Folia Microbiol 45, 128-132.

5. Greiner R, da Silva LG \& Couri S (2009) Purification and characterisation of an extracellular phytase from Aspergillus niger 11t53a9. Braz.J Microbiol 40, 795-807.

6. Greiner R, Konietzny U \& Jany KD (1993) Purification and characterization of two phytases from Escherichia coli. Arch Biochem Biophys 303, 107-113.

7. Greiner R, Carlsson NG \& Alminger ML (2000) Stereospecificity of myo-inositol hexakisphosphate dephosphorylation by a phytatedegrading enzyme of Escherichia coli. J Biotechnol 84, 53-62.

8. Maenz DD \& Classen HL (1998) Phytase activity in the small intestinal brush border membrane of the chicken. Poultry Sci 77, $557-563$.

9. Applegate TJ, Angel R \& Classen HL (2003) Effect of dietary calcium, 25-hydroxycholecalciferol, or bird strain on small intestinal phytase activity in broiler chickens. Poultry Sci 82, 1140-1148.

10. Abudabos AM (2012) Intestinal phytase activity in chickens (Gallus domesticus). Afr J Microbiol Res 6, 4932-4938.

11. Leytem AB, Willing BP \& Thacker PA (2008) Phytate utilization and phosphorus excretion by broiler chickens fed diets containing cereal grains varying in phytate and phytase content. Anim Feed Sci Tech 146, 160-168.

12. Tamim NM \& Angel R (2003) Phytate phosphorus hydrolysis as influenced by dietary calcium and micro-mineral source in broiler diets. J Agric Food Chem 51, 4687-4693.

13. Tamim NM, Angel R \& Christman M (2004) Influence of dietary calcium and phytase on phytate phosphorus hydrolysis in broiler chickens. Poultry Sci 83, 1358-1367.

14. Kerr MJ, Classen HL \& Newkirk RW (2000) The effects of gastrointestinal tract micro-flora and dietary phytase on inositol hexaphosphate hydrolysis in the chicken. Poultry $S_{c i}$ 79, Suppl. 1, 11 (abstract).

15. Leytem AB, Thacker PA \& Turner BL (2007) Phosphorus characterization in feces from broiler chicks fed low-phytate barley diets. J Sci Food Agr 87, 1495-1501.

16. Schlemmer U, Jany KD, Berk A, et al. (2001) Degradation of phytate in the gut of pigs -pathway of gastrointestinal inositol phosphate hydrolysis and enzymes involved. Arch Anim Nutr 55, 225-280.

17. Kemme PA, Schlemmer U, Mroz Z, et al. (2006) Monitoring the stepwise phytate degradation in the upper gastrointestinal tract of pigs. J Sci Food Agr 86, 612-622.

18. Pontoppidan K, Glitsoe V, Guggenbuhl P, et al. (2012) In vitro and in vivo degradation of myo-inositol hexakisphosphate by a phytase from Citrobacter braakii. Arch Anim Nutr 66, 431-444.

19. Rodehutscord M (2009) Approaches and challenges for evaluating phosphorus sources for poultry. In Proceedings of the 17th European Symposium on Poultry Nutrition, pp. 2-6 [WPSA UK Branch, editor]. Edinburgh, Scotland.

20. Abelson PH (1999) A potential phosphate crisis. Science 283, 2015.

21. Campbell GL \& Bedford MR (1992) Enzyme applications for monogastic feeds: a review. Can J Anim Sci 72, 449-466.

22. Gesellschaft für Ernährungsphysiologie (Society for Nutrition Physiology) (1999) Empfeblungen zur Energie- und Nährstoffversorgung der Legehennen und Masthühner (Broiler) (Recommendations for the Energy and Nutrient Supply of Laying Hens and Broilers), 1st ed. Frankfurt am Main: DLG Verlag.

23. Rodehutscord M, Dieckmann A, Witzig M, et al. (2012) A note on sampling digesta from the ileum of broilers in phosphorus digestibility studies. Poultry Sci 91, 965-971.

24. Verband Deutscher Landwirtschaftlicher Untersuchungs- und Forschungsanstalten (Association of German Agricultural Testing and Research Institutes) (2006) Handbuch der landwirtschaftlichen Versuchs- und Untersucbungsmethodik. (VDLUFA-Methodenbuch), vol.3: Die Chemische Untersuchung von Futtermitteln (Handbook of Agricultural Testing and Research Methodology (VDLUFA Method Book), vol 3: The Chemical Control of Feed), 1st ed., Darmstadt: VDLUFA-Verlag.

25. Boguhn J, Baumgärtel T, Dieckmann A, et al. (2009) Determination of titanium dioxide supplements in different matrices using two methods involving photometer and inductively coupled plasma optical emission spectrometer measurements. Arch Anim Nutr 63 337-342.

26. Shastak Y, Witzig M, Hartung K, et al. (2012) Comparison of retention and prececal digestibility measurements in evaluating mineral phosphorus sources in broilers. Poultry Sci 91, 2201-2209.

27. Phillippy BQ \& Bland JM (1988) Gradient ion chromatography of inositol phosphates. Anal Biochem 175, 162-166.

28. Chen QC \& Li BW (2003) Separation of phytic acid and other related inositol phosphates by high-performance ion chromatography and its applications. J Chromatogr A 1018, 41-52.

29. Skoglund E, Carlsson NG \& Sandberg AS (1997) Determination of isomers of inositol mono- to hexaphosphates in selected foods and intestinal contents using high-performance ion chromatography. J Agric Food Chem 45, 431-436.

30. Svihus B, Hetland H, Choct M, et al. (2002) Passage rate through the anterior digestive tract of broiler chickens fed on diets with ground and whole wheat. Br Poultry Sci 43, 662-668.

31. Raghavendra P \& Halami PM (2009) Screening, selection and characterization of phytic acid degrading lactic acid bacteria from chicken intestine. Int J Food Microbiol 133, 129-134.

32. Marounek M, Skřivan M, Rosero O, et al. (2010) Intestinal and total tract phytate digestibility and phytase activity in the digestive tract of hens fed a wheat-maize-soyabean diet. I Anim Feed Sci 19, 430-439.

33. Sacranie A, Svihus B, Denstadli V, et al. (2012) The effect of insoluble fiber and intermittent feeding on gizzard development, gut motility, and performance of broiler chickens. Poultry Sci 91, 693-700.

34. Brüning P (2009) In-vitro- und in-vivo-Untersuchungen zur Effizienz verschiedener mikrobieller Phytasen als Futterzusatzstoff (In vitroand in vivo-studies on the efficiency of various microbial phytases as a feed additive). $\mathrm{PhD}$ Thesis, Free University Berlin.

35. Igbasan FA, Männer K, Miksch G, et al. (2000) Comparative studies on the in vitro properties of phytases from various microbial origins. Arch Anim Nutr 53, 353-373.

36. Garrett JB, Kretz KA, O'Donoghue E, et al. (2004) Enhancing the thermal tolerance and gastric performance of a microbial phytase for use as a phosphate-mobilizing monogastric-feed supplement. Appl Environ Microbiol 70, 3041-3046.

37. Elkhalil EAI, Männer K, Borriss R, et al. (2007) In vitro and in vivo characteristics of bacterial phytases and their efficacy in broiler chickens. Br Poultry Sci 48, 64-70.

38. Leytem AB, Widyaratne GP \& Thacker PA (2008) Phosphorus utilization and characterization of ileal digesta and excreta from broiler chickens fed diets varying in cereal grain, phosphorus level, and phytase addition. Poultry Sci 87, 2466-2476.

39. Leslie MA (2006) Effect of phytase and glucanase, alone or in combination, on nutritive value of corn and soybean meal fed to broilers. PhD Thesis, Auburn University, AL.

40. Leytem AB, Kwanyuen P, Plumstead PW, et al. (2008) Evaluation of phosphorus characterization in broiler ileal digesta, manure, and litter samples: ${ }^{31}$ P-NMR vs. HPLC. J Environ Qual 37, 494-500.

41. Elkhalil EAI, Osman HAH \& Simon O (2011) Phytic acid anaylsis by different bacterial phytases. Aust J Basic Appl Sci 5, 2295-2302.

42. Van der Kaay J \& Van Haastert PJM (1995) Stereospecificity of inositol hexakisphosphate dephosphorylation by Paramecium phytase. Biochem J 312, 907-910.

43. Haros M, Carlsson NG, Almgren A, et al. (2009) Phytate degradation by human gut isolated Bifidobacterium pseudocatenulatum ATCC27919 and its probiotic potential. Int J Food Microbiol 135, 7-14. 
44. Greiner R, Konietzny U \& Jany KD (1998) Purification and properties of a phytase from rye. J Food Biochem 22, 143-161.

45. Phillippy BQ (1999) Susceptibility of wheat and Aspergillus niger phytases to inactivation by gastrointestinal enzymes. J Agric Food Chem 47, 1385-1388.

46. Greiner R, Jany KD \& Larsson Alminger M (2000) Identification and properties of myo-inositol hexakisphosphate phosphohydrolases (phytases) from barley (Hordeum vulgare). J Cereal Sci 31, 127-139.

47. Greiner R, Muzquiz M, Burbano C, et al. (2001) Purification and characterization of a phytate-degrading enzyme from germinated faba beans (Vicia faba var. Alameda). I Agric Food Chem 49, 2234-2240.

48. Greiner R, Haller E, Konietzny U, et al. (1997) Purification and characterization of a phytase from Klebsiella terrigena. Arch Biochem Biophys 341, 201-206.

49. Kerovuo J, Lauraeus M, Nurminen P, et al. (1998) Isolation, characterization, molecular gene cloning, and sequencing of a novel phytase from Bacillus subtilis. Appl Environ Microbiol 64, 2079-2085.

50. Lan GQ, Abdullah N, Jalaludin S, et al. (2002) Culture conditions influencing phytase production of Mitsuokella jalaludinii, a new bacterial species from the rumen of cattle. J Appl Microbiol 93, 668-674.

51. Lopez HW, Vallery F, Levrat-Verny MA, et al. (2000) Dietary phytic acid and wheat bran enhance mucosal phytase activity in rat small intestine. J Nutr 130, 2020-2025.

52. Barrientos L, Scott JJ \& Murthy PPN (1994) Specificity of hydrolysis of phytic acid by alkaline phytase from lily pollen. Plant Physiol 106, 1489-1495.

53. Puhl AA, Greiner R \& Selinger LB (2008) A protein tyrosine phosphatase-like inositol polyphosphatase from Selenomonas ruminantium subsp. lactilytica has specificity for the 5-phosphate of myo-inositol hexakisphosphate. Int J Biochem Cell B 40, 2053-2064.

54. Yoon SJ, Choi YJ, Min HK, et al. (1996) Isolation and identification of phytase-producing bacterium, Enterobacter sp. 4, and enzymatic properties of phytase enzyme. Ensyme Microb Tech 18, 449-454.
55. Escobin-Mopera L, Ohtani M, Sekiguchi S, et al. (2012) Purification and characterization of phytase from Klebsiella pneumoniae 9-3B. J Biosci Bioeng 113, 562-567.

56. Greiner R, Farouk A, Alminger ML et al. (2002) The pathway of dephosphorylation of myo-inositol hexakisphosphate by phytatedegrading enzymes of different Bacillus spp. Can J Microbiol 48, 986-994.

57. Palacios MC, Haros M, Rosell CM, et al. (2008) Selection of phytate-degrading human bifidobacteria and application in whole wheat dough fermentation. Food Microbiol 25, 169-176.

58. Sasirekha B, Bedashree T \& Champa KL (2012) Statistical optimization of medium components for improved phytase production by Pseudomonas aeruginosa. Int J Chem Tech Res 4, 891-895.

59. Lu J, Idris U, Harmon B et al. (2003) Diversity and succession of the intestinal bacterial community of the maturing broiler chicken. Appl Environ Microbiol 69, 6816-6824.

60. Wyss M, Pasamontes L, Friedlein A, et al. (1999) Biophysical characterization of fungal phytases (myo-inositol hexakisphosphate phosphohydrolases): molecular size, glycosylation pattern, and engineering of proteolytic resistance. Appl Environ Microbiol 65, 359-366.

61. Persson H, Türk M, Nyman M, et al.(1998) Binding of $\mathrm{Cu}^{2+}, \mathrm{Zn}^{2+}$, and $\mathrm{Cd}^{2+}$ to inositol tri-, tetra-, penta-, and hexaphosphates. J Agric Food Chem 46, 3194-3200.

62. Cowieson AJ, Wilcock P \& Bedford MR (2011) Super-dosing effects of phytase in poultry and other monogastrics. World Poultry Sci J 67, 225-235.

63. Aydin A, Pekel AY, Issa G, et al. (2010) Effects of dietary copper, citric acid, and microbial phytase on digesta $\mathrm{pH}$ and ileal and carcass microbiota of broiler chickens fed a low available phosphorus diet. I Appl Poultry Res 19, 422-431.

64. Yu S, Cowieson A, Gilbert C, et al. (2012) Interactions of phytate and myo-inositol phosphate esters (IP1-5) including IP5 isomers with dietary protein and iron and inhibition of pepsin. J Anim Sci 90, 1824-1832. 